\title{
Salafi dan Sikapnya Terhadap Penguasa
}

\author{
Ainul Haris \\ STAI Ali bin Abi Thalib Surabaya \\ yam2908@gmail.com
}

\section{Pendahuluan}

Saat ini, gerakan salafi menjadi sorotan. Hal itu tidak lepas dari berbagai peristiwa pengeboman yang oleh sebagian pengamat disinyalir dilakukan oleh kelompok salafi. Terakhir dan mudah-mudahan ini benarbenar menjadi peristiwa pengeboman terakhir di Indonesia- masyarakat Indonesia dan dunia dikagetkan oleh pengeboman hotel JW. Marriot dan Ritz Carlton di Jakarta pada hari Jum'at, 17 Juli 2009. Salah seorang mantan anggota DPR, yang juga mantan intelejen, Soeripto dalam suatu wawancara di MetroTV selepas peristiwa pengeboman hotel JW. Marriot dan Ritz Carlton mengatakan, pemerintah perlu mewaspadai kelompok salafi. Meski tidak secara langsung, Soeripto memang sedang mengarahkan opini bahwa orang-orang salafi patut dicurigai sebagai pelaku pengeboman tersebut.

Salafi sendiri sebagai sebuah gerakan dan atau manhaj (cara memahami agama) tidaklah tunggal. Secara umum, salafi di Indonesia ada dua "madzhab". Yang pertama adalah salafi jihadi yang fokus kegiatannya pada aksi jihad demikian mereka menamakan- yang dalam implementasinya disinyalir banyak melakukan kegiatan terorisme dan pengeboman. Yang kedua adalah salafi arus utama yang menentang konsep jihad menurut salafi jihadi. ${ }^{1}$ "Madzhab" salafi arus utama lebih menfokuskan pada bidang pendidikan dan dakwah yang damai serta menghindari hingar-bingar politik. ${ }^{2}$

Salafi sebagai sebuah gerakan dakwah dalam formatnya yang marak sekarang, terutama di kampus-kampus umum, masjid,

1 Greg Fealy dan Anthony Bubalo, Jejak Kafilah, Pengaruh Radikalisme Timur Tengah di Indonesia, (Bandung: Mizan Pustaka, 2007), 124-125. Lihat pula hasil penelitian International Crisis Group, Indonesia Backgrounder: Why Salafism And Terrorism Mostly Don't Mix (International Crisis Group, 2004), 25-29.

2 Ibid., 123. 
kantor/instansi dan perumahan menengah atas- mulai tumbuh di Indonesia pada sekitar tahun $19800^{3}$ Menurut hasil penelitian International Crisis Group (ICG), fenomena berkembangnya salafi pada tahun 80-an dikarenakan beberapa faktor di antaranya adalah: 1) Ketersediaan dana; terutama dari Saudi Arabia; 2) Adanya halaqahhalaqah kampus; 3) Berkembangnya penerbitan Islam; 4) Terjadinya perang di Afganistan; 5) Berdirinya LIPIA (Lembaga Ilmu Pengetahuan Islam dan Arab). ${ }^{4}$ Menurut Agus Hasan Basori, salah seorang da'i senior salaf di Malang dan pemimpin umum majalah Qiblati yang bermanhaj salaf, para pelopor gerakan salafi adalah alumni dari berbagai universitas di Timur Tengah, utamanya Saudi Arabia. Misi dakwah mereka adalah mengembalikan umat Islam kepada tauhid, dan menghindarkan mereka dari shirik, bid'ah dan khurafat. Ciri dakwah mereka adalah sangat berhati-hati dalam menyampaikan ilmu. Mereka takut jika terjerumus dalam kesalahan pemahaman, sehingga menyimpang dari pemahaman alsalaf al-sālih, apalagi jika sampai jatuh pada bid'ah dan shirik. Karena itu, dalam berdakwah mereka selalu membawa rujukan buku yang dikarang oleh ulama mu'tabar di kalangan salafi. Biasanya buku tersebut juga sudah ada sharah (penjelasannya) dari ulama salaf. Sehingga mereka tinggal menyampaikan atau mengalihbahasakan. Dalam menjawab masalah-masalah kontemporer dan "berat" kaum salafi di Indonesia masih belum berani memberi fatwa langsung. Bahkan, meskipun da'i yang dianggap paling senior di antara mereka. Jika menghadapi masalah-masalah besar tersebut mereka menanyakan kepada para ulama yang ada di Timur Tengah. Di antara ulama-ulama tersebut waktu itu adalah Shaikh Abdul Azīz bin Abdullāh bin Bāz, Shaikh Muhammad Nāshiruddīn al-Albāni, Shaikh Muhammad bin Shālih alUtsaimīn, Shaikh Muhammad bin Jibrīn, Shaikh Shālih al-Fauzān, Shaikh Muqbil bin Hādi, Shaikh Ali Hasan al-Atsari, Shaikh Sālim bin

3 Ibid., 121.

4 International Crisis Group, Indonesia Backgrounder, 10. 
Ied al-Hilāly, Shaikh Mashūr Salmān, Shaikh Ibrāhīm al-Ruhaili dan lain-lain. ${ }^{5}$

Adapun dakwah salaf di Indonesia, dalam pengertian dakwah kepada pemurnian tauhid dan pemberantasan shirik, pembersihan Islam dari semua kotoran ajaran yang bukan dari Islam, kembali kepada AlQur'an dan hadis dengan penafsiran yang ketat sudah dimulai sejak zaman Imam Padri (Imam Bonjol) di Sumatera Barat pada awal abad sembilan belas, yakni dalam rentang waktu antara 1803-1832. Lalu di wilayah Jawa diteruskan oleh Ahmad Shurkati dengan organisasi AlIrshadnya pada awal abad 20, kemudian oleh KH. Ahmad Dahlan dengan organisasi Muhammadiyah pada tahun 1912, dan Persis di Bandung pada tahun $1923 .{ }^{6}$ Tetapi Ja'far Umar Thālib ${ }^{7}$, salah seorang pelopor dakwah

5 Agus Hasan Basori, wawancara, Surabaya, 21 Desember 2009.

6 Muhammad Ikhsan, "Gerakan Salafi Modern di Indonesia, Sebuah Upaya Membedah Akar, Pertumbuhan dan Ide-ide Substansinya”, dalam http://alquranandsunnah-wordpress.com/2009/02/05/gerakan-salafi-modern-diindonesia/\#more-1025 (20 Desember 2009). Lihat pula International Crisis Group, Indonesia Backgrounder, 10.

7 Ja'far Umar Thālib adalah salah satu tokoh gerakan dakwah salafi di Indonesia tahun '90-an. Dialah pendiri sekaligus pemimpin redaksi majalah Salafy yang merupakan media utama kaum salafi Indonesia waktu itu. Dia juga adalah pimpinan Pondok Salafi Degolan, Yogyakarta. Kisah kehidupan dakwah Ja'far Umar Thālib sungguh sangat unik dan penuh romantika. Mulanya ia adalah seorang pengagum berat Sayid Quthb, Hasan al-Banna dan tokoh-tokoh Ikhwān al-Muslimīn secara umum. Namun setelah mengenal dakwah salaf, Sayid Quthb, Hasan al-Bannā dan tokoh-tokoh Ikhwān al-Muslimin lainnya ia hujat habis-habisan, terutama melalui majalah Salafy yang ia pimpin. Ia kemudian menjadi Komandan Lashkar Jihad, untuk membela kaum muslimin di Ambon, Maluku yang tengah berperang dengan orang-orang Kristen di sana. Ja'far adalah orang yang keras dalam menvonis orang-orang yang berseberangan dengan dakwahnya. Para da'i yang menurutnya menyimpang, pasti ia kecam habis-habisan, baik melalui ceramah maupun tulisan. Sekitar tahun 2004, Ja'far aktif sebagai penceramah di pengajian dzikir Muhammad Arifin Ilham. Saat itu, para "musuh"nya menghujatnya habis-habisan, karena dalam pandangan mereka pengajian model Arifin Ilham dengan dzikir bersamanya adalah menyimpang dari sunnah. Hal yang dulunya sangat diperangi oleh Ja'far sendiri. Ja'far bergeming, wajahnya sering menghiasi layar kaca bersama Arifin Ilham. Setelah itu, dikabarkan ia dekat dengan pihak istana, terutama RI 2 (Jusuf Kalla) waktu itu. Bahkan 
salaf di tahun '90-an mengklaim bahwa dakwah salaf di Indonesia sudah berlangsung sejak zaman Sultan Iskandar Muda di Aceh (1603-1637). ${ }^{8}$

Pada tahun '90-an, salafi arus utama mulai retak. Mereka saling mengklaim bahwa kelompoknya lah yang lebih salafi dari yang lain. ${ }^{9}$ Secara kasat mata perpecahan tersebut di antaranya dimulai dengan mubāhalah (perang doa antara dua kubu agar yang salah dilaknat oleh Allah) antara kelompok Yusuf Ba'isa dengan Ja'far Umar Thālib. Sampai pada berdirinya Lashkar Jihad, lalu munculnya kelompok salafi Yamani dan berbagai kelompok lain yang biasanya ditandai dengan mendirikan ma'had (pondok pesantren) atau yayasan. Tetapi bila dipetakan, perpecahan di tubuh salafi arus utama dapat dibagi menjadi tiga kelompok besar. Yaitu salafi Yamani, salafi Saudi, dan salafi Urduni (Yordania). Ketiga kelompok tersebut ulama rujukan akhirnya masingmasing adalah ulama Yaman, ulama Saudi dan ulama Yordania. Secara institusi, kelompok Yamani diwakili oleh di antaranya Ma'had al-Sunnah Makassar, pimpinan Ust. Dzū al-Qornain, Ma'had Ihyā' Sunnah Yogyakarta, pimpinan Muhammad Sewed dan Ma'had Al-Bayyinah, Sedayu Gresik. Secara institusi salafi Saudi diwakili di antaranya oleh Ma'had Imām Shāfi'i, Cilacap. Sedang institusi yang mewakili salafi Urduni di antaranya adalah Ma'had Imam Bukhari Solo, Ma'had Minhāj al-Sunnah Bogor, Ma'had al-Furqān, Gresik. Selain ketiga kelompok salafi arus utama tersebut, masih ada satu kelompok lain dari salafi arus utama, yaitu kelompok yang tidak memihak kepada salah satu dari kelompok arus utama tersebut. Kelompok keempat ini biasanya lebih mudah beradaptasi dengan lingkungan dan memiliki manajemen yang rapi di dalam berdakwah. Institusi yang mewakili kelompok ini di antaranya adalah Wahdah Islāmiyah, Makassar, Jam'iyyah al-Najāt,

dikatakan Ja'far diangkat sebagai penasihat spiritual JK. Ja'far memang orangnya kharismatik, sangat pandai melobi dan ahli bertutur kata. Setelah banyak bergaul dengan para pejabat dan kalangan aghniy $\bar{a}^{\prime}$ (orang-orang kaya) dakwah Ja'far saat ini sungguh sangat sejuk, tidak pernah menghujat dan selalu berusaha memberi solusi, khususnya untuk persatuan umat Islam.

8 Muhammad Ikhsan, Gerakan Salafi Modern,3.

9 Greg Fealy dan AnthonyBubalo, Jejak Kafilah, 121. 
Jakarta, Ma'had al-Binā' Tangerang, Yayasan al-Sofwa, Jakarta dan Yayasan Nidā' al- Fithrah, Surabaya. ${ }^{10}$

Ada juga pendapat yang mengatakan bahwa salafi arus utama hanya terpecah menjadi tiga kelompok. Yaitu salafi Yamani, salafi Urduni dan salafi moderat. Salafi moderat biasanya rujukan ulamanya adalah para ulama dari Saudi Arabia. Karena itu, memang agak sulit untuk mencari institusi yang bisa mewakili kelompok salafi Saudi, karena salafi Saudi lebih cenderung moderat dan toleran dibanding salafi lainnya. Ma'had Imām al-Shāfi'i Cilacap misalnya, yang dikelompokkan termasuk kategori salafi Saudi, menurut pengelompokan pendapat pertama, adalah pondok pesantren yang dikenal moderat, tidak eksklusif dan terbuka dengan ulama dari mana pun, asal pemahaman mereka sesuai dengan pemahaman al-salaf al-sālih. ${ }^{11}$

Fenomena yang unik dari perpecahan di tubuh salafi arus utama adalah meskipun perseteruan di antara kelompok-kelompok tersebut sangat tajam, namun buku daras (ajar) mereka adalah sama, manhaj dan pemahaman mereka juga sama. Bahkan terhadap para ulama besar rujukan mereka yang sebagian besar sudah wafat, seperti Shaikh Muhammad Nāshirudd̄̄n al-Albāni, Shaikh Bin Bāz, Shaikh Ibnu

10 Cahyo Suprayogo, wawancara, Surabaya, 25 Februari 2010.

11 Ustad Agus Hasan Basori, salah seorang dai salafi senior dan pemimpin umum majalah Qiblati yang bermanhaj salaf menyatakan ketidaksetujuannya terhadap adanya pengelompokan salafi menjadi beberapa kelompok. Menurut beliau, salafi adalah bukan sekte atau kelompok tertentu. Salafi dalam pengertian sebagai manhaj (cara memahami agama) adalah satu. Salafi menembus sekat-sekat perbedaan suku, warna kulit, bahasa dan sebagainya, karena salafi tidaklah miliki golongan atau kelompok tertentu. Dengan demikian, salafi juga bukan milik dan klaim kelompok tertentu. Karena itu, siapa saja yang komitmen dalam memahami ajaran Islam sesuai dengan yang dipahami oleh para sahabat dari Rasulullah Saw. maka dia adalah salafi, baik dia itu orang Indonesia, Yaman, Amerika, atau Saudi Arabia, baik dia itu berada di organisasi atau yayasan manapun. Agus Hasan Basori, wawancara, 22 Desember 2009. Menurut Hartono Ahmad Jaiz, seorang penulis produktif terutama tentang aliran-aliran sesat, pengelompokan tersebut adalah agenda pihak luar untuk memecah belah salafi, khususnya di Indonesia. (Hartono Ahmad Jaiz, wawancara, 20 Desember 2009) 
Utsaimīn, Shaikh Bin Jibrīn dan lainnya mereka semua menerima dan sepakat. Bahkan ulama-ulama lini kedua, yang mereka jadikan rujukan secara terpisah, sebenarnya adalah murid-murid dari ulama lini pertama. Selain itu, para ulama lini kedua tersebut juga saling menghormati, meskipun kadang terjadi perbedaan pendapat di antara mereka dalam masalah-masalah fiqih. Seperti Shaikh Ali Hasan al-Atsari, Shaikh Sālim bin Īed al-Hilāly, Shaikh Mūsā Ālu Nasr, Shaikh Muhammad al-Dausari, Shaikh Muhammad bin Muhammad Mukhtār al-Shinqīthi, Shaikh Yahyā al-Najmi dan lain-lain. Sebagian analisa mengatakan bahwa perpecahan di antara mereka bukanlah masalah manhaj (cara memahami agama), tetapi lebih karena persoalan-persoalan kepentingan pribadi, kurangnya ilmu dan wawasan, kecintaan berlebihan kepada shaikh tertentu dan sejenisnya. ${ }^{12}$

\section{Salafi Jihadi}

Salafi jihadi adalah salafi yang menfokuskan kegiatannya pada jihad dalam pengertian fisik melawan orang-orang kafir. Mereka melakukan kegiatannya dengan sangat rapi dan terorganisir. Meskipun salafi arus utama terbelah menjadi paling tidak tiga kelompok utama, dan mereka saling berbeda pendapat dalam implementasi dakwah di lapangan, tetapi mereka bersepakat untuk menolak konsep jihad menurut salafi jihadi. Dan sejatinya, ulama rujukan mereka juga berbeda. Jika ulama rujukan salafi arus utama pada lini pertama adalah sama, bahkan buku-buku daras mereka juga sama, berbeda halnya dengan salafi jihadi. Ulama rujukan mereka berbeda dengan ulama rujukan salafi arus utama. Di antara ulama rujukan salafi jihadi adalah Abdullah Azzam, Osama bin Laden, Ayman al-Zhawāhiri dan Abū Qatāda. Sebagian orang yang dijadikan rujukan oleh salafi jihadi bukanlah ulama. Seperti Osama bin Laden, ia lebih sebagai aktifis jihad daripada sebagai ulama, demikian juga dengan yang lainnya. ${ }^{13}$

12 Agus Hasan Basori, wawancara, 22Desember 2009.

13 Greg Fealy dan Anthony Bubalo, Jejak Kafilah, 125. 
Bila dirunut ke belakang, gerakan jihad Imrān bin Muhammad Zain sekitar tahun 80-an, oleh sebagian kalangan juga dimasukkan sebagai gerakan salafi jihadi. Tetapi sebagian lain menolak memasukkannya sebagai gerakan salafi jihadi karena Imrān memba'iat anggotanya yang sebanyak 190 orang pada Juni 1980 di Cimahi, Jawa Barat sebelum melancarkan aksi jihad. Hal yang tidak dikenal dalam ajaran salafi jihadi. ${ }^{14}$

Pada bulan Maret 1981, lima anggota jamaah Imran membajak pesawat Garuda DC-9 Woyla dan memaksa pilotnya terbang serta mendarat di Bandara Don Muang, Bangkok. Pasukan Komando Indonesia kemudian menyerbu pesawat itu dan berhasil membunuh empat dari lima pembajaknya. Pembajak kelima akhirnya mati secara misterius ketika dibawa pulang ke Jakarta. Imran sendiri tertangkap pada 7 April 1981 di Jakarta. la dimejahijaukan di Pengadilan Negeri Jakarta pada penghujung 1981 dan akhirnya dinyatakan bersalah, serta dijatuhi hukuman mati berdasarkan undang-undang subversi (UU no. 11/PNPS/1963). Pada penghujung Mei 1983, Imran menjalani eksekusi. ${ }^{15}$

Pada tanggal 1 Januari 1993, Abdullah Sungkar mendirikan Jamāah Islamiyah (JI) yang oleh para pengamat diidentikkan sebagai institusi yang mewakili salafi jihadi. Seperti al-Qāeda, JI adalah gerakan transnasional. Mayoritas pimpinan dan anggotanya dari Indonesia, lalu Malaysia, Singapura, Philipina, Thailand dan beberapa negara Asia Tenggara lainnya. Tujuan formal JI adalah mendirikan khilafah di kawasan Asia Tenggara yang memungkinkan penerapan shariat Islam, sebagai basis pemulihan khilāfah islāmiyah secara universal. ${ }^{16}$

14 Sebagian kalangan yang memasukkan gerakan Imrān sebagai gerakan salafi jihadi beralasan bahwa Imrān telah belajar agama di Arab Saudi antara 1971-1976, sementara Arab Saudi adalah asal gerakan salafi. Lihat Tempo interaktif, "Wendy, Abu, Icuh dan Ju", dalam http://majalah. tempointeraktif.com /id/arsip/1981/04/11/NAS/mbm.19810411.NAS49234.id.html (22 Februari 2010)

15 Indonesia Faithfreedom, "Upaya Pembentukan Negara Islam NII dan Penerapan Syariat Islam", dalam http://indonesia.faithfreedom.org/forum/upaya-pembentukannegara-islam-nii-dan-penerapan-syariat-t10521 (22 Februari 2010)

16 Ibid., 127. 
Sebagian dari pelaku pengeboman di Indonesia, memang dengan terang-terangan mengaku bahwa dirinya adalah seorang salafi, seperti Imam Samudera, pelaku pengeboman di Legian Bali, 12 Oktober 2002. Imam Samudera dalam "Halaman Persembahan" bukunya Aku Melawan Teroris menulis:

"Bingkisan buat:

Ayah dan bunda tercinta yang telah sekian lama tak bersua, dan kedua orang mertua yang saya hormati, semoga dirahmati Allah.

Bidadariku dan sekalian cahaya mataku yang kucintai dan kukasihi semoga Allah merahmati kalian...

Seluruh ikhwan Mujahidin senasib seperjuangan yang telah dan sedang diuji di bawah siksaan, tekanan dan kini kuliah di '"Kampus Teroris"'semoga lulus dan istiqamah.

Seluruh '"partner"' diskusi di alam maya, yang akan segera paham manhaj Salafush shāleh, bukan '"salafush shāleh"' (dalam tanda petik). Keluarga shuhada Jihad Bom Bali dan bom lainnya, semoga diberi kesabaran oleh Allah dan turut mendapat shafa'at di akhirat kelak..". ${ }^{17}$

Imam Samudera menulis alasan pengeboman tersebut, ..yang terjadi adalah bangsa-bangsa penjajah itu telah, sedang dan akan terus membantai warga sipil bangsa-bangsa muslim. Akan tetapi Amerika dan sekutunya telah melampaui batas. Allah Maha Suci, Allah Maha Benar! Allah tidak membiarkan hamba-hamba-Nya terus berada di dalam kebimbangan dan kehinaan oleh kaum kafir. Perang dibalas perang, darah dibalas darah, nyawa dibalas nyawa, pelampauan batas dibalas dengan setimpal. Maka memerangi warga sipil (kalau memang benar sipil) dari bangsa-bangsa penjajah adalah tindakan yang wajar dilakukan demi keseimbangan dan keadilan. Darah dibalas darah, nyawa dibalas nyawa dan sipil dibalas sipil. Itulah keseimbangan. ${ }^{18}$

Pengeboman yang terjadi di JW. Marriot dan Ritz Carlton Jakarta pada hari Jum'at, 17 Juli 2009 juga oleh sebagian pengamat

17 Imam Samudera, Aku Melawan Teroris (Solo: Jazeera, 2004), 5.

18 Ibid., 116. 
sebagaimana telah disinggung di muka- dikaitkan dengan gerakan salafi. Nurdin M. Top sebagai pemimpin kegiatan tersebut juga seorang yang mengaku sebagai salafi. Dalam keterangannya di sebuah situs, yang disinyalir sebagai situs resminya, ia mengatakan bahwa pengeboman tersebut adalah Amaliyāt Jihädiyah Istishādiyah. Ia mengatakan bahwa alasan pengeboman tersebut adalah:

1. Sebagai qisas (pembalasan yang setimpal) atas perbuatan yang dilakukan oleh Amerika dan antek-anteknya terhadap saudara kami kaum muslimin dan mujahidin di penjuru dunia.

2. Menghancurkan kekuatan mereka di negeri ini, yang mana mereka adalah pencuri dan perampok barang-barang berharga kaum muslimin di negeri ini.

3. Mengeluarkan mereka dari negeri-negeri kaum muslimin. Terutama dari negeri Indonesia.

4. Menjadi pelajaran buat ummat Islam akan hakikat Walā' (Loyalitas) dan Baro' (Permusuhan), terkhusus menghadapi datangnya Klub Bola MANCESTER UNITED (MU) ke hotel tersebut. Para pemain itu terdiri dari para salibis. Maka tidak pantas ummat ini memberikan wala'nya dan penghormatannya kepada musuh-musuh Allah ini.

5. Amaliyāt Istishādiyah ini sebagai penyejuk dan obat hati buat kaum muslimin yang terzalimi dan tersiksa di seluruh penjuru dunia."19

Berbagai tindak kekerasan dan terorisme juga banyak dilatarbelakangi oleh pandangan bahwa pemerintah dan penguasa muslim, bahkan kaum muslimin telah kafir. Kelompok yang berideologi takfiri (mudah mengkafirkan umat Islam lain) tersebut di antaranya banyak dipengaruhi oleh tulisan-tulisan para intelektual muslim, seperti Sayid Quthb. Misalnya dalam tafsir F̄̄ Zhilāl al-Qur'ān, Sayid Quthb menulis, "Zaman telah berputar seperti pada saat ia datang dengan kalimat Lā ilāha illallāh. Manusia telah murtad, sehingga menyembah

19 Indra Subagja, "Surat Pengakuan Nur Din M. Top atas Tragedi Marriot dan Ritz", dalam http://www. detiknews.com/read/2009/07/29 (22 Februari 2010) 
kepada sesama manusia, agama menjadi alat berbuat aniaya dan bertolak belakang dari esensi Là ilāha illallāh. Manusia secara umum, termasuk mereka yang biasa melantunkan kalimat Lā ilāha illallāh di menaramenara masjid, di timur dan di barat, tanpa memahami makna dan merealisasikannya, mereka itu akan mendapat dosa dan siksa yang lebih berat pada hari Kiamat. Sebab, mereka telah berbalik menyembah kepada sesama manusia, padahal telah jelas bagi mereka petunjuk, dan setelah mereka berada di dalam agama Allah." 20

Shaikh Yūsuf Qaradhāwi bahkan menegaskan bahwa pemikiran dan ideologi terakhir Sayid Quthb adalah ideologi takfiri. ${ }^{21}$ Shaikh Qaradhāwi juga menyimpulkan bahwa pemikiran Quthb merupakan kombinasi antara Ikhwan, Salafi, dan Jihadi." Betapapun demikian, Shaikh Qaradhāwi tetap tidak bisa menyembunyikan kekagumannya terhadap ketokohan Sayid Quthb, ia mengatakan, "Sayyid Quthb adalah sastrawan, pemikir, cendikiawan, penafsir, dan tokoh Islam terbesar pada masanya." Namun demikian, tambah Qaradhāwi, Quthb adalah orang yang paling bertanggung jawab atas berkembangnya aliran pemikiran radikal yang sekarang marak di kalangan sebagian umat Islam. ${ }^{22}$

Makalah ini akan menyoroti persoalan sikap salaf yang sesungguhnya berdasarkan pemahaman para ulama salaf yang punya ororitas- terhadap penguasa yang sah, dan apakah pemahaman mereka (yang mengaku salafi tersebut), khususnya dalam sikap terhadap pemerintah yang sah yang berujung pada berbagai tindak anarkis, seperti pengeboman dan sebagainya sesuai dengan ajaran kaum al-salafu al-sālih atau menyelisihinya.

20 Sayid Quthb, F̄̄ Zhilāl al-Qur'ān, vol.4 (Dār al-Shurūq, 1980), 2122.

21 Ibrāhīm bin Amīr al-Ruhaili, al-Takfı̌r wa Dhawābituh (Dar Imam Ahmad, 2008), 41.

22 Yūsuf al-Qaradhāwi, "Quthb Bertanggung Jawab atas Berkembangnya Islam Radikal", dalam http://dunia.pelajar-islam or.id/dunia.pii/2009/08/10 (20 Desember, 2009) 


\section{Makna Salaf Secara Bahasa}

Salaf secara bahasa berasal dari akar kata salafa artinya yang terdahulu. Salaf menurut Ibnu Fāris berarti orang-orang yang telah lalu. ${ }^{23}$ baik dari sisi ilmu, keimanan, keutamaan atau jasa kebaikan. Seorang pakar bahasa Arab Ibnu Manzhur mengatakan, Kata salaf juga berarti orang yang mendahului kamu, yaitu nenek moyangmu, sanak kerabatmu yang berada di atasmu dari sisi umur dan keutamaan. Oleh karenanya maka generasi awal yang mengikuti para sahabat disebut dengan al-salaf al-sālih (pendahulu yang baik)." ${ }^{24}$ Makna semacam ini serupa dengan kata salaf yang terdapat di dalam ayat Allah yang artinya, "Maka tatkala mereka membuat Kami murka, Kami menghukum mereka lalu Kami tenggelamkan mereka semuanya di laut dan Kami jadikan mereka sebagai salaf (pelajaran) dan contoh bagi orang-orang kemudian. ${ }^{25}$ Maksudnya, Kami menjadikan mereka sebagai pelajaran pendahulu bagi orang yang melakukan perbuatan sebagaimana perbuatan mereka, supaya orang sesudah mereka mau mengambil pelajaran dan mengambil nasihat darinya. $^{26}$

Dengan demikian kita bisa serupakan makna kata salaf ini dengan istilah nenek moyang dan leluhur dalam bahasa kita. Dalam kamus Islam kata ini bukan barang baru. Pada jaman Nabi Muhammad kata ini sudah dikenal. Seperti terdapat dalam riwayat Muslim, Nabi Muhammad Saw. kepada puterinya Fathimah bersabda, "Sesungguhnya sebaik-baik salafmu adalah aku." (HR. Muslim). Maksudnya sebaik-baik pandahulu. ${ }^{27}$ Oleh sebab itu secara bahasa, semua orang terdahulu adalah salaf. Baik yang jahat seperti Fir'aun, Qarun, Abu Jahal, maupun yang

23 Ibnu Fāris, Mu'jamu Maqāyis al-Lughah, vol. 1, (Riyādh: Dār Thaibah, 1416H), 567.

24 Ibnu Manzhūr, Lisān al-Arab, vol. 9 (Riyādh: Dār Alam al-Kutub, 1416H), 159.

25 al-Qur'ān, 43 (al-Zukhruf): 55-56.

26 Abdullah bin Abdul Hamid al-Atsari, Al-Wajīz fì Aqīdati al-Salaf al-Sālih, (Dār Ibnu Huzaimah, tt.), 20.

27 Yazīd Abdul Qāadir Jawas, Sharah Aqīdah Ahlu al-Sunnah wa al-Jamāah (Bogor: Dār al-Taqwā, 2007), 7. 
baik seperti Nabi-Nabi, para shuhada dan orang-orang salih dari kalangan sahabat dan lain-lain.

\section{Definisi Salaf di Kalangan Para Ulama}

Para ulama berbeda pendapat tentang definisi "salaf". ${ }^{28}$ Di antara pendapat tersebut adalah pendapat yang mengatakan bahwa salaf adalah para sahabat dan tābi'în. Di antara yang menguatkan pendapat ini adalah Imam al-Ghazali, di mana beliau mengatakan, "Ketahuilah bahwa kebenaran yang nyata yang tidak ada pertentangan di dalamnya menurut para ahli ilmu adalah madzhab salaf, yaitu para sahabat dan tābi'în. ${ }^{29}$

Pendapat lain mengatakan, bahwa salaf adalah para sahabat, tābi'în dan tābi'it tāâi'in, serta yang mengikuti mereka dengan baik dari para imam kaum muslimin. Pendapat ini banyak dinukil oleh para penulis kitab akidah dari kalangan Ahlu al-Sunnah wa al-Jamā'ah, hal

28 Meskipun tidak dalam lingkup pembahasan definisi salafiyah yang dimaksud dalam makalah ini, kiranya perlu tetap disinggung tentang makna salafiyah dalam pengertian lain. Departemen agama (Depag) dalam kategorisasinya tentang pendidikan Islam, menggunakan kata salafiyah sebagai sekolah yang hanya mengajarkan mata pelajaran agama. Ini bukan berarti bahwa sekolah tersebut mengikuti ajaran salafi sebagaimana yang kini berkembang. Fenomena di lapangan menunjukkan, sebagian besar dari madrasah salafiyah tersebut adalah cenderung moderat dan berhaluan Nahdhatul Ulama. Lihat International Crisis Group, Indonesia Backgrounder,6. Namun kategorisasi Departemen agama tersebut tidaklah sepenuhnya benar. Sebagai contoh adalah pesantren Tebu Ireng yang didirikan pada tahun 1899M oleh KH. Hashim Ash'ari.. Tebu Ireng adalah tergolong pesantren salafiyah. Namun pada tahun 1929M ketika KH. Ilyas ditunjuk oleh KH. Hashim Ash'ari menjadi kepala Madrasah Salafiyah di Tebu Ireng beliau memasukkan pengetahuan umum ke dalam madrasah salafiyah, sehingga korankoran, majalah dan buku umum pun masuk ke pesantren Tebu Ireng, dan dibaca oleh para kyai dan santri. Itu sebelum zaman kemerdekaan. Saat ini pesantren Tebu Ireng sebagai pesantren salafiyah memiliki sarana, fasilitas dan lembaga pendidikan modern hingga jenjang perguruan tinggi. Lihat Zuhairini, et.al. Sejarah Pendidikan Islam. (Jakarta: Bumi Aksara, 2008), 203-204.

29 Imām Abū Hamid al-Ghazāli, Iljāmu al-Awām an Ilmi al-Kalām (Dār al-Fikr alLubnāni, 1993), 53. 
mana merupakan tazkiyah (rekomendasi) kepada mereka yang mengikuti jalan para sahabat Rasulullah Saw. dan para pengikutnya. ${ }^{30}$

Al-Safarayini mengatakan: "Salaf adalah orang-orang terdahulu dari kalangan Muhajirin dan Anshar serta seluruh sahabat Nabi Muhammad, dan orang-orang yang mengikuti mereka dengan baik, kemudian para imam petunjuk setelah mereka yang disepakati oleh kaum muslimin bahwa mereka berada di atas petunjuk dan ilmu, serta meneladani mereka (para sahabat dan tābi'īn) dan berjalan di atas jalan mereka." 31

Komisi Tetap untuk Penelitian Ilmiah dan Fatwa Saudi Arabia mendefinisikan salaf sebagai berikut, "Salaf yaitu para sahabat Rasulullah Saw. dan para imam petunjuk dari tiga generasi pertama kaum muslimin." 32

Shaikh Sālim al-Hilāly menerangkan, "Adapun secara terminologi kata salaf berarti suatu karakter yang melekat secara mutlak pada diri para sahabat. Adapun para ulama sesudah mereka juga tercakup dalam istilah ini karena sikap dan cara beragama mereka yang meneladani para sahabat." 33

Shaikh Nāshir bin Abdul Karīm al-'Aql mengatakan, "Salaf adalah generasi awal umat ini, yaitu para sahabat, tabi' 'in dan para imam pembawa petunjuk pada tiga generasi yang mendapatkan keutamaan (sahabat, tābi'în dan tābi'ut tābi'ìn). Dan setiap orang yang meneladani dan berjalan di atas manhaj mereka di sepanjang masa disebut sebagai salafi sebagai bentuk penisbatan terhadap mereka." 34

30 Isā bin Nāsir al-Daraibi, Min Ma'ālim al-Taisir fì Tafsīri al-Salaf (Saudi Arabia: Wizārah Syu'ūn Islāmiyah, 1428H), 164.

31 Ibid, hal. 164.

32 Himpunan Ulama Besar Saudi Arabia, Fatāwā Lajnah Dā'imah, vol. 2 (Wizārah Shu'ūn Islāmiyah, 1428), 166.

33 Sālim bin Ied al-Hilāly, Limādzā Ikhtartu al-Manhaj al-Salafi (Markaz al-Dirāsāt al-Manhajiyyah al-Salafiyyah, 1420), 30.

34 Nāsir bin Abdul Karīm al-Aql, Mujmal Ushūl Ahli al-Sunnah wa al-Jamāah fì alAqìdah (Dar Ma'ārif, 1427H), 5-6. 
al-Qalshāni di dalam kitabnya Tahrīru al-Maqālah min Sharhi alRisalah mengatakan, "Adapun al-salaf al-sālih mereka adalah generasi awal Islam yang mendalam ilmunya serta meniti jalan Nabi Muhammad dan senantiasa menjaga Sunnah beliau. Allah telah memilih mereka untuk menemani Nabi-Nya dan menegakkan agama-Nya. Para imam umat ini pun merasa ridha kepada mereka. Mereka telah berjihad di jalan Allah dengan penuh kesungguhan. Mereka kerahkan daya upaya mereka untuk menasihati umat dan memberikan kemanfaatan bagi mereka. Mereka juga mengorbankan diri demi menggapai keridhaan Allah. ${ }^{35}$ Rasulullah bersabda, "Sebaik-baik orang adalah di jamanku (sahabat), kemudian orang sesudah mereka (tabi'in) dan kemudian orang sesudah mereka (tabi'ut tabi 'inn)." 36

Dari berbagai definisi salaf yang disampaikan oleh para ulama sebagaimana tersebut di atas maka dapat disimpulkan bahwa Rasulullah Saw. beserta para sahabatnya adalah salaf umat ini. Demikian pula setiap orang yang menyerukan dakwah sebagaimana mereka, juga disebut sebagai orang yang menempuh manhaj/metode salaf, atau biasa disebut dengan istilah salafi, artinya pengikut salaf. Adapun pembatasan istilah salaf hanya meliputi masa sahabat, tabi 'ìn dan tabi'ut tabi'în adalah pembatasan yang lemah secara argumentatif. Karena pada masa itu pun sudah muncul tokoh-tokoh yang menyimpang dari manhaj salaf. Akan tetapi kriteria yang benar adalah kesesuaian akidah, hukum dan perilaku mereka dengan al-Kitāb dan al-Sunnah serta pemahaman al-salafu alsālih (Nabi dan para sahabatnya). Oleh karena itu, siapa pun orangnya, hidup di masa kapan pun dan di daerah mana pun, apabila dia mengamalkan ajaran al-Kitāb dan al-Sunnah sesuai dengan pemahaman al-salaf al-sālih (Nabi Muhammad dan para sahabat) maka berarti dia adalah pengikut salaf (salafi), meskipun jarak dan masanya jauh dari periode kenabian. Ini artinya orang-orang yang semasa dengan Nabi dan

35 Sālim bin Ied al-Hilāly, Limādzā Ikhtartu, 31 .

36 Diriwayatkan oleh Imām Bukhari dalam Sahīhnya, Kitāb Fadhāilu al-Shahābah, Bāb Fadhā'ilu Ashābi al-Nabi; Muslim dalam Sahihnya Kitāb Fadhāilu alShahābah, hadis no. 210, 211,212. 
sahabat, akan tetapi tidak beragama sebagaimana mereka maka bukanlah termasuk golongan mereka, meskipun orang-orang itu sesuku atau bahkan saudara Nabi Muhammad. ${ }^{37}$

\section{Beberapa Contoh Penggunaan Kata "Salaf"}

Kata salaf sering digunakan oleh Imam Bukhāri di dalam kitab Sahihnya. Imam Bukhāri mengatakan, "Rashīd bin Sa'ad berkata, Para salaf menyukai kuda jantan. Karena ia lebih lincah dan lebih berani." alHāfizh Ibnu Hajar menafsirkan kata salaf tersebut, "Maksudnya adalah para sahabat dan orang sesudah mereka." Shaikh Sālim mengatakan, "Yang dimaksud oleh Rashīd adalah para sahabat. Karena Rashīd bin Sa'ad adalah seorang tābi'īn (murid sahabat), sehingga orang yang disebut salaf olehnya adalah para sahabat, tanpa ada keraguan sedikitpun." Demikian pula perkataan Imam Bukhari, al-Zuhri mengatakan mengenai tulang bangkai semacam gajah dan selainnya, 'Aku menemui sebagian ulama salaf yang bersisir dengannya (tulang) dan menggunakannya sebagai tempat minyak rambut. Mereka memandangnya tidaklah mengapa.' Shaikh Sālim mengatakan, "Yang dimaksud (dengan salaf di sini) adalah para sahabat Nabi Muhammad Saw. karena al-Zuhri adalah seorang tābi'în." ${ }^{38}$

Kata salaf juga digunakan oleh Imam Muslim di dalam kitab Sahihnya. Di dalam mukaddimahnya Imam Muslim mengeluarkan hadis dari jalan Muhammad bin 'Abdullah. Ia (Muhammad) mengatakan, "Aku mendengar "Ali bin Shaqīq mengatakan, Aku mendengar Abdullah bin al-Mubārak mengatakan di hadapan orang banyak, "Tinggalkanlah hadis (yang dibawakan) 'Amr bin Tābit. Karena dia mencaci kaum salaf." Shaikh Sālim mengatakan, "Yang dimaksud adalah para sahabat."39

Kata salaf juga sering dipakai oleh para ulama akidah di dalam kitab-kitab mereka. Contohnya sebuah riwayat yang dibawakan oleh

37 Yaz̄id Abdul Qādir Jawas, Sharah Aqīdah, 8.

38 Sālim bin Īed al-Hilāly, Limādzā Ikhtartu, 31-32.

39 Ibid., 32. 
Imam al-Ajūri di dalam kitabnya yang berjudul al-Sharī'ah bahwa Imām Auzā'i pernah berpesan, "Bersabarlah engkau di atas Sunnah. Bersikaplah sebagaimana kaum itu (salaf) bersikap. Katakanlah sebagaimana yang mereka katakan. Tahanlah dirimu sebagaimana sikap mereka menahan diri dari sesuatu. Dan titilah jalan salafmu yang shalih. Karena sesungguhnya sudah cukup bagimu apa yang membuat mereka cukup." Shaikh Salim mengatakan, "Yang dimaksud adalah para sahabat, karena al-Auzā'i adalah seorang tābi'în."

\section{Kedudukan Manhaj Salaf}

Allah berfirman, "Dan barangsiapa yang menentang Rasul sesudah jelas petunjuk baginya, dan mengikuti jalan yang bukan jalan orang-orang mukmin, Kami biarkan ia leluasa terhadap kesesatan yang telah dikuasainya itu dan Kami masukkan ia ke dalam Jahannam, dan Jahannam itu seburuk-buruknya tempat kembali. "41

Ketika ayat ini diturunkan, orang-orang mukmin yang dimaksud adalah para sahabat Nabi. Bahkan Allah telah meridhai mereka dan orang-orang sesudahnya yang mengikuti mereka serta menjanjikan untuk mereka balasan yang besar. Allah berfirman, "Orang-orang yang terdahulu lagi yang pertama-tama (masuk Islam) di antara orang-orang Muhajirīn dan Anshār dan orang-orang yang mengikuti mereka dengan baik, Allah ridha kepada mereka dan mereka pun ridha kepada Allah, Allah telah menyediakan bagi mereka surga-surga yang mengalir sungai-sungai di dalamnya; mereka kekal di dalamnya selama-lamanya. Itulah kemenangan yang besar." 4243

Maka, kata salaf atau salafiyah dalam pengertian di atas, yakni mengikuti dan mencontoh kepada Nabi dan para sahabat adalah Islam itu

40 Ibid., 32.

41 al-Qur'ān, 4 (al-Nisa'): 115.

42 al-Qur'ān, 9 (al-Taubah): 100.

43 Lihat, Muhammad Jamīl Zainu, Jalan Golongan yang Selamat, terj. Ainul Hāris Umar Arifin Thayib (Jakarta: Darul Haq, 1998), 12. 
sendiri. Islam yang murni dari pengaruh-pengaruh peradaban lama dan warisan berbagai kelompok menyimpang. ${ }^{44}$ Islam yang sebagaimana digambarkan dalam hadis Ibnu Mas'ūd:, "Rasulullah membuat satu garis lurus, lalu beliau membuat garis-garis lain di samping kanan dan kiri garis itu lalu beliau bersabda. 'Ini adalah jalan Tuhanmu yang lurus, dan jalan-jalan ini, pada setiap jalan tersebut ada setan yang menyeru kepadanya, lalu beliau membaca ayat, "Dan sesungguhnya inilah jalanKu yang lurus maka ikutilah ia, dan jangan mengikuti jalan-jalan lain, sehingga kalian akan bercerai-berai dari jalan-Nya. "45 46

Dalam konteks mengikuti manhaj salaf, sahabat Abdullah bin Mas'ūd berkata, "Barangsiapa ingin mengambil sunnah (pedoman, jalan) maka hendaklah ia mengambil sunnah dari orang-orang yang sudah mati. Karena orang yang hidup masih belum aman dari fitnah. Mereka (orangorang yang sudah mati itu) adalah para sahabat Nabi Muhammad. Mereka adalah orang-orang yang paling utama dari umat ini. Hati mereka paling bersih, ilmu mereka paling mendalam, dan mereka paling tidak memaksakan diri. Mereka adalah orang-orang yang dipilih oleh Allah untuk menemani Nabi-Nya dan menegakkan agama-Nya. Karena itu, kenalilah keutamaan mereka! Ikutilah jejak mereka! Berpegang teguhlah sesuai kemampuan kalian dengan akhlak dan agama mereka. Karena sesungguhnya mereka berada di atas petunjuk yang lurus." 47

44 Ini adalah pengertian normatifnya. Sehingga tidak berarti bahwa setiap orang yang mengaku sebagai salafi (pengikut manhaj salaf) otomatis menjadi seorang muslim kaffah (secara totalitas). Sama halnya dengan adanya perbedaan antara Islam sebagai ajaran yang sempurna dengan orang muslim sebagai pemeluk agama Islam. Tidak setiap muslim merepresentasikan Islam yang sebenarnya. Sehingga, di tengah masyarakat ada istilah Islam KTP (Kartu Tanda Penduduk), Islam abangan dan sebagainya.

45 al-Qur'ān, 6 (al-An'am): 153.

46 Hadis riwayat al-Hākim dalam al-Mustadrak, (2/239), ia berkata, "Hadis ini sanadnya shahih," dan pernyataannya tersebut disetujui oleh al-Dzahabi. Lihat Ahmad Salām, Mā Ana Alaihi wa Ashābī, (Dār Ibn Hazm, 1995), 43.

47 Diriwayatkan dengan redaksi yang hampir sama oleh Ibnu Abdi al-Bar dalam Jāmi Bayān al-Ilmi wa Fadhlih, dari jalur Sunaid. Lihat Ibnu Abi al-Izzi, Sharah Aqīdah Thahāwiyah, vol. 2 (Riyādh: al-Majlis al-Islāmi al-Āsiawi, 121H), 546. 


\section{Keabsahan Penamaan Salaf}

Kata "salafiyah" memang belum digunakan oleh Rasul dan para sahabat karena pada saat itu hal ini belum dibutuhkan. Pada saat itu kaum muslimin generasi awal masih hidup di dalam pemahaman Islam yang sahih, sehingga tidak dibutuhkan penamaan khusus seperti ini. Mereka bisa memahami Islam dengan murni tanpa perlu khawatir akan adanya penyimpangan karena Rasulullah Saw. masih berada di antara mereka. Hal ini sebagaimana mereka mampu berbicara dengan bahasa Arab yang fasih tanpa perlu mempelajari ilmu Nahwu, Sharaf dan Balaghah. Namun tatkala muncul berbagai kekeliruan dan penyimpangan dalam penggunaan bahasa Arab, muncullah ilmu-ilmu bahasa Arab tersebut demi meluruskan kembali pemahaman dan menjaga keutuhan bahasa Arab. Maka demikian pula dengan istilah salafiyah.

Ketika sekian banyak penyimpangan pemahaman bertebaran di tengah-tengah kaum muslimin maka dianggap perlu adanya ramburambu yang jelas demi mengembalikan pemahaman Islam kepada pemahaman yang murni dan lurus. Apalagi mayoritas kelompok yang menyerukan pemahaman yang berseberangan dengan pemahaman yang lurus itu juga mengaku sebagai pengikut al-Qur'ān dan al-Sunnah. Berdasarkan realita inilah para ulama berupaya memisahkan pemahaman yang masih murni ini dengan pemahaman-pemahaman lainnya dengan nama pemahaman ahli hadis, salaf atau ahlu al-sunnah wa al-jamā'ah. ${ }^{48}$

Jika istilah Hanbali (pengikut fikih Imām Ahmad bin Hanbal), Hanafi (pengikut fikih Imām Abu Hanifah), Shāfi'i (pengikut fikih Imām Shāfi'i), Māliki (pengikut fikih Imām Mālik), telah disepakati oleh kaum muslimin tentang kebolehannya maka sesungguhnya istilah salafi (pengikut para sahabat) dari sisi ini, lebih patut untuk diterima, karena derajat para sahabat adalah derajat yang lebih tinggi dari para imam kaum muslimin tersebut yang nota bene adalah tābi'īn dan atau tābiut tābi'în. Sebab para sahabat telah dipuji oleh Allah dan Rasul-Nya dan terjaga secara umum dari bersepakat dalam kesalahan. Adapun Hanbali,

48 Sālim bin Īed al-Hilāly, Limādza Ikhtartu, 36. 
Hanafi, Shāfi'i, Maliki dan lainnya adalah penisbatan kepada individu dan kelompok yang tidak terdapat dalil tegas tentang keutamaannya, serta tidak ada jaminan terbebas dari kesalahan mereka secara kelompok. Maka, jika kaum muslimin bisa menerima penisbatan kepada pribadi dan kelompok yang tidak ma'süm (terpelihara dari kesalahan), tentu menerima penisbatan kepada salaf (para sahabat) lebih layak untuk diterima, karena Allah telah menyatakan ridha terhadap mereka. ${ }^{49}$

\section{Sikap Salaf terhadap Penguasa}

Islam telah mengatur pokok-pokok hubungan antara rakyat dengan penguasa. Di antara pokok-pokok ajaran Islam yang telah dijalankan oleh para al-salaf al-sālih dalam perkara tersebut adalah kewajiban taat kepada penguasa yang sah. Tentang ketaatan kepada penguasa ini, hingga ada pemeo di kalangan para al-salaf al-sālih, "Enam puluh tahun bersama penguasa yang zalim (dengan tetap mentaatinya), itu adalah lebih baik daripada semalam tanpa penguasa." 50

Nabi Saw. bersabda,

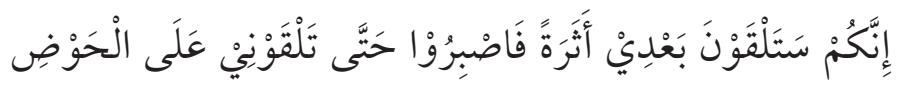

"Sesungguhnya kalian nanti akan menemui atsarah (pemerintah yang tidak memenuhi hak rakyat'). Maka bersabarlah hingga kalian menemuiku di haudl" 51

al-Imām al-Nawāwi berkata, "Di dalam hadits ini terdapat anjuran untuk mendengar dan taat kepada penguasa, walaupun ia seorang yang zalim dan sewenang-wenang. Maka berikan haknya (sebagai pemimpin) yaitu berupa ketaatan, tidak keluar ketaatan darinya, dan tidak menggulingkannya. Bahkan perbuatan yang seharusnya dilakukan oleh

49 Mūsā Nasr, Silsilah Abhāts Manhajiyyah al-Salafiyyah (Dār Ma'rifah, 1428H), 6667.

50 Khālid al-Anbari, Fiqh al-Siyāsah al-Shar'iyah, (Dār Minhāj, 1428H), 121.

51 Hadis riwayat al-Bukhāri, hadis no. 7057 dan Muslim, no. 1845. 
seorang muslim adalah dengan sungguh-sungguh lebih mendekatkan diri kepada Allah, supaya Dia menyingkirkan gangguan dan siksaan darinya, menolak kejahatannya, dan agar Allah memperbaikinya (kembali taat kepada Allah meninggalkan kezalimannya)",52

Kewajiban mendengar dan taat kepada penguasa adalah dalam seluruh perkara yang bukan maksiat kepada Allah, karena tidak boleh taat kepada makhluk dalam soal kemaksiatan kepada Allah. Dalil-dalil yang menerangkan prinsip tersebut di antaranya adalah, "Hai orangorang yang beriman, ta'atilah Allah dan ta'atilah Rasul-Nya, dan ulil amri di antara kamu. Kemudian jika kamu berlainan pendapat tentang sesuatu maka kembalikanlah ia kepada Allah (al-Qur'an) dan Rasul (Sunnahnya), jika kamu benar-benar beriman kepada Allah dan Hari Kemudian. Yang demikian itu adalah lebih utama (bagimu) dan lebih baik akibatnya. "53 Ibnu Taimiyah menyatakan, "Ulil Amri mencakup dua golongan, yaitu ulama dan penguasa."54

Rasulullah Saw. bersabda, "Setiap muslim wajib mendengar dan taat (kepada penguasa) dalam perkara yang ia senangi dan ia benci kecuali apabila diperintah berbuat kemaksiatan. Apabila penguasa memerintah berbuat kemaksiatan maka tidak perlu didengar dan ditaati (kemaksiatan itu)." 55 al-Hāfizh Ibnu Hajar al-Asqalāni menyatakan, "Hadis ini menunjukkan wajibnya taat kepada penguasa, hal itu berlaku dalam perkara yang bukan maksiat. Hikmah taat kepada penguasa adalah agar menjaga persatuan kaum muslimin, karena perpecahan adalah berarti kehancuran." 56

52 Imām Nawāwi, Sharah Sah̄̄h Muslim, vol. 12 (Matba'ah Misriyah bi al-Azhar. 1349H), 232.

53 al-Qur'ān, 4 (al-Nisa'): 59.

54 Ibnu Taimiyah, Majmu’ Fatāwā, vol. 18 (Dār al-Malayin, tt.), 158. Lihat pula Imāduddīn Abū al-Fida' Ismāīl bin Katsīr al-Qurasyi al-Dimashqi, Tafsīr al-Qur'ān al-Adzīm, vol.1 (Riyādh: Maktabah Faihā',1414H), 530.

55 Hadis riwayat Bukhari dan Muslim.

56 al-Hāfizh Ahmad bin Ali bin Hajar al-Asqalāni, Fathu al-Bāri bi Syarh Shahīh alBukhāri, vol 13 (Dār al-Fikr, tanpa tahun ), 112. 
Rasulullah Saw. bersabda, "Aku wasiatkan kepada kalian untuk bertakwa kepada Allah, mendengar dan taat walaupun (yang memerintah kalian) seorang budak Habasyi (yang hitam). ${ }^{157}$ Beliau juga bersabda,

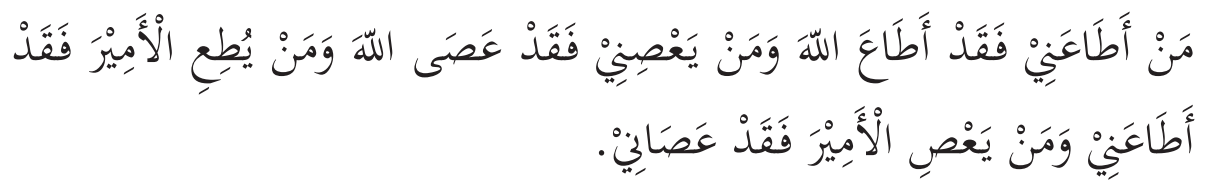

"Barangsiapa taat kepadaku berarti ia telah mentaati Allah, dan barangsiapa bermaksiat kepadaku berarti ia telah bermaksiat kepada Allah. Dan barangsiapa yang taat kepada amir (yang Muslim) maka ia taat kepadaku dan barangsiapa bermaksiat kepada amir maka ia bermaksiat kepadaku. ${ }^{158}$

Para al-salafu al-sālih sepakat bahwasanya taat kepada penguasa (pemerintah) adalah wajib. Banyak ucapan ulama besar Ahlu al-Sunnah tentang wajibnya taat kepada pemimpin dan akibat buruk dari membangkang terhadap mereka. Al-Imam al-Barbahari berkata, "Barangsiapa memegang kekuasaan dengan kesepakatan kaum muslimin dan mereka ridha kepadanya maka ia adalah amìrul mukmininn. Haram bagi seorang yang beriman kepada Allah dan Hari Akhir untuk melewati malamnya dengan tidak menganggapnya sebagai seorang pemimpin, baik pemimpin itu orang sālih maupun orang fājir (pendosa)."

al-Imām Ibnu Hajar al-Asqalāni berkata, "Para ulama telah sepakat atas wajibnya taat kepada pemimpin yang menang dalam memperebutkan kekuasaan dan wajib jihad bersamanya. Taat kepadanya lebih baik daripada membangkang kepadanya, karena hal tersebut akan mencegah pertumpahan darah dan menciptakan ketenangan rakyat." 59

Akan tetapi kewajiban taat kepada penguasa tersebut dibatasi oleh Rasulullah Saw. dengan sabdanya,

57 Hadis riwayat Tirmidzi dan dishahihkan oleh al-Albānī.

58 Muttafaq Alaih.

59 al-Hāfizh Ahmad bin Ali bin Hajar al-Asqalāni, Fathu al-Bāri, 113. 


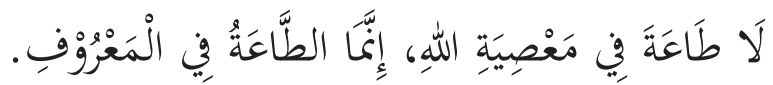

"Tidak boleh taat terhadap perintah bermaksiat kepada Allah, sesungguhnya ketaatan itu hanya dalam hal yang ma'ruf (kebaikan). "60

Meskipun demikian, terhadap individu penguasanya, sebagaimana dikatakan oleh Imam al-Barbahari, kewajiban mentaati tersebut bersifat umum, sama saja kepada penguasa yang baik atau yang zalim selama mereka masih muslim dan mengerjakan salat. Inilah keyakinan para al-salafu al-sālih. Mereka lebih mendahulukan nash-nash shar'i dan tidak mengikuti hawa nafsu. Akidah dan keyakinan para alsalaf al-sālih ini berbeda dengan keyakinan sebagian kelompok Islam yang membolehkan memberontak apabila melihat penguasa berlaku zalim, seperti Khawārīj, atau kelompok yang terlalu menganggap suci penguasa, hingga meyakini mereka $m a$ 'süm (tidak punya dosa dan salah), sehingga tidak berani menasihatinya, betapapun kemungkaran yang ada, seperti kaum Shi'ah Rāfidhah. ${ }^{61}$

\section{Prinsip-Prinsip Sikap Rakyat terhadap Penguasa Menurut al-Salaf al-Sālih}

Selain prinsip ketaatan kepada penguasa dalam perkara yang $m a^{\prime} r \bar{f}$ (kebaikan) sebagai prinsip dasar, Islam mengatur bagaimana seharusnya sikap rakyat terhadap penguasanya, agar hubungan tersebut berjalan dengan harmoni, sehingga terbentuklah sebuah masyarakat islami yang ideal. Di antara prinsip-prinsip tersebut adalah:

\section{Pertama: Meyakini wajibnya bai'at terhadap penguasa}

Orang yang menjadi khalifah secara suka-rela, di mana kaum

60 Muttafaq Alaih.

61 Abdu al-Salām Barjas, Muamalatu al-Hukkām fì Dhau' al-Kitāb wa al-Sunnah (Dammam: Dār Sabīl al-Mukminīn, 1414H), 6. Lihat pula Ainul Haris, "Ciri-ciri Golongan yang Benar dan Selamat", dalam 30 Wasiat Takwa di Bulan Puasa (Riyādh: Dār al-Kitāb wa al-Sunnah, 2009), 90. 
muslimin sepakat dan ridha kepadanya, atau karena khalifah tersebut dapat menundukkan mereka dengan kekuatan, sehingga ia menjadi khalifah (pemimpin kaum muslimin) maka kaum muslimin wajib taat kepadanya dan haram keluar dari ketaatan kepadanya. Nabi Muhammad bersabda,

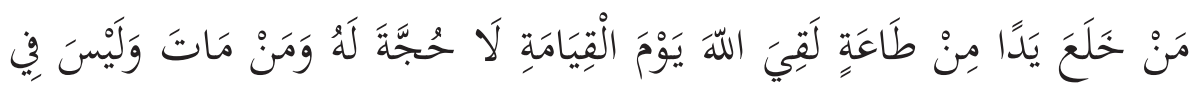

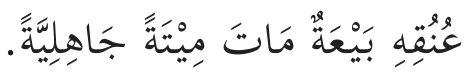

"Barangsiapa melepaskan ketaatan (dari penguasa), niscaya ia akan menjumpai Allah dalam kondisi tanpa memiliki hujjah. Dan barangsiapa meninggal tanpa ikatan bai'at maka kematiannya seperti kematian jahiliyyah. ${ }^{\prime 62}$ Hadis ini menunjukkan wajibnya berbai'at kepada seorang penguasa yang telah mampu mengendalikan kondisi sosial masyarakat di bawah kekuasaannya, dan haram untuk keluar dari ketaatan terhadap penguasa tersebut; baik dia sālih atau fājir. Barangsiapa yang tidak mempunyai niatan untuk berbai'at kepadanya atau tidak meyakini kewajibannya maka ketika dia mati, kematiannya sama dengan kematian orang-orang jahiliyah. ${ }^{63}$

Bai'at tersebut hanyalah kepada khalifah atau amīr al-mukminin, tidak kepada yang lainnya, dan tidak berarti setiap kaum muslimin harus mendatangi amīr al-mukminin atau wakilnya untuk berjabat tangan, tapi cukup untuk meniatkan dan meyakini kewajiban taat kepadanya. Sebab tidak pernah diceritakan bahwa ketika Abu Bakar, Umar, Utsman, atau Ali bin Abi Thalib menjadi khalifah, kaum Muslimin berbondong-

62 Hadis riwayat Muslim.

63 Ada salah tafsir terhadap hadis di atas oleh beberapa kelompok pergerakan, di antaranya seperti LDII (Lembaga Dakwah Islam Indonesia) di mana mereka maksudkan bai'at tersebut ditujukan kepada pemimpin jama'ah LDII, dan mewajibkan kepada setiap individu untuk membai'atnya, dan barangsiapa tidak melaksanakannya maka dianggap kafir. Padahal maksud hadis tersebut adalah bai'at kepada pemimpin kaum muslimin (amīr al-mukminīn) yang telah disepakati. Dalam konteks keindonesiaan, amīr al-mukminīn (penguasa kaum muslimin) Indonesia yang sah saat ini adalah Bapak Susilo Bambang Yudhoyono. 
bondong mendatangi mereka untuk berjabat tangan, tapi yang membai'at mereka secara langsung hanyalah ahlu al-halli wa al-'aqdi.

\section{Kedua: Menghormati penguasa}

Islam sangat memuliakan penguasa, hal itu karena beratnya tugas yang mereka emban. Tidak seorang pun boleh menjelek-jelekan penguasa, baik dengan celaan, ghibah (gunjingan) atau yang lainnya. Rasulullah Saw. bersabda, "Para penguasa adalah naungan Allah di muka bumi. Barangsiapa yang memuliakan penguasa, Allah akan memuliakannya. Barangsiapa yang menghina penguasa, Allah akan menghinakan dia. ${ }^{\prime 64}$ Beliau Saw. juga bersabda, "Jangan kalian mencela penguasa kalian, jangan kalian menipu dan membencinya. Bertakwa dan bersabarlah kepada Allah, sesungguhnya perkaranya dekat. "65

Imām Ibnu Abi Ashim meriwayatkan dari Muawiyah bin Abi Sufyan, dia berkata, "Ketika Abū Dhar keluar menuju Robadhah, dia bertemu dengan sekelompok penduduk Iraq. Mereka berkata, 'Wahai Abū Dhar, kami sudah tahu apa yang dilakukan penguasa atasmu, duduklah dan pasangkanlah bendera pemberontakan, orang-orang akan berhimpun bersamamu.' Abū Dzar berkata, 'Tenang... tenang wahai saudara se-islam, sesungguhnya aku mendengar Rasulullah bersabda, 'Akan ada sepeninggalku para penguasa. Hormatilah mereka, barangsiapa yang mencari-cari keburukannya, sungguh dia telah meruntuhkan dinding Islam. Tidak akan diterima taubatnya, sehingga dia mengembalikan dinding yang dirusakkannya itu sebagaimana awalnya. ${ }^{66}$

Sahl bin Abdullāh al-Tusturi berkata, "Manusia akan senantiasa berada di dalam kebaikan selama mereka menghormati penguasa dan para ulama. Apabila mereka mengagungkan dua golongan ini, Allah akan memperbaiki dunia dan akhirat mereka. Apabila mereka

64 Abū Bakar Ahmad bin Al-Husain al-Baihaqi, Shu'abu al-Imān, vol. 17 (Beirut: Dār al-Kutub al-Ilmiyyah, 1410H), 6.

65 Ibid., vol. 6, 69.

66 Hadis riwayat Ibnu Abi Ashim. 
merendahkannya, berarti mereka telah menghancurkan dunia dan akhirat mereka sendiri." 67

\section{Ketiga: Menasihati penguasa secara rahasia}

Amar ma'ruf nahi munkar merupakan salah satu asas yang sangat penting di dalam agama Islam. Tegaknya amar ma'ruf nahi munkar akan melahirkan kebaikan serta menghapuskan berbagai kebatilan dan kemunkaran. Allah berfirman, "Dan hendaklah ada di antara kamu segolongan umat yang menyeru kepada kebajikan, menyuruh kepada yang ma'ruf dan mencegah dari yang munkar, mereka itu adalah orangorang yang beruntung. " 68

Rasulullah bersabda,"Barangsiapa melihat kemunkaran maka ubahlah dengan tangannya. Apabila tidak mampu maka dengan lisannya. Apabila tidak mampu maka dengan hatinya, dan itulah selemah-lemah iman." 69

Ibnu Nuhas berkata, "Mencegah kesalahan penguasa tidak boleh dengan kekuatan tangan, tidak boleh mengangkat senjata, atau mengumpulkan orang untuk memberontak, karena akan membangkitkan fitnah, menimbulkan keburukan dan menjatuhkan kewibawaan penguasa, bahkan bisa mendorong rakyat untuk memberontak, menghancurkan negeri dan yang seumpamanya, serta berbagai kejelekan yang tidak samar lagi." Imam Ahmad berkata, "Penguasa tidak boleh ditentang, karena pedangnya terhunus." ${ }^{70}$ Imām Ibnu Muflih berkata, "Tidak boleh bagi seorang pun untuk mengingkari penguasa, kecuali dengan nasihat

67 al-Imām Abū Abdillah al-Qurthubi, al-Jāmi' li Ahkāmi al-Qur'ān, vol. 5 (Riyādh: Dār Alam al-Kutub, 2003), 260.

68 al-Qur'ān, 3 (Ali Imran): 104.

69 Hadis riwayat Muslim, hadis no. 49; Ahmad, vol.3, hadis no.10; Abū Daud, hadis no. 1140; Tirmidzi, hadis no. 2172; Nasa'i, vol.8, hadis no.111; Ibnu Majah, hadis no.1275; Ibnu Hibbān, hadis no.306.

70 Muhammad bin Muflih bin Muhammad al-Maqdisi, al-Ādāb al-Shar'iyyah wa alMinah al-Mar'iyyah, vol. 1 (Alamu al-Kutub, tt.), 197. 
dan peringatan dari hukuman dunia dan akhirat, hal itu wajib dan selain itu tidak boleh." ${ }^{71}$

Rasulullah Saw. bersabda, "Barangsiapa yang hendak menasihati penguasa, janganlah ia menampakkannya secara terang-terangan, akan tetapi hendaklah ia memegang tangannya, kemudian bersendirian dengannya. Apabila penguasa itu mau menerima nasihat maka itulah yang diinginkan. Apabila tidak, sesungguhnya dia (yang menasihati) telah menunaikan kewajibannya. "72 Usamah bin Zaid pernah ditanya, "Tidakkah engkau menemui Utsmān kemudian menasihatinya?" Beliau menjawab, "Apakah kamu pikir aku tidak menasihatinya, kecuali harus memberitahumu?! Sungguh aku telah menasihatinya dengan empat mata, dan aku tidak ingin membuka rahasia."73 al-Hāfizh Iyādh berkata, "Maksud Usāmah adalah dia tidak ingin membuka pintu pengingkaran kepada penguasa secara terang-terangan, karena khawatir timbul akibat yang buruk. Bahkan hendaklah mengingkari dengan lemah-lembut, menasihati secara rahasia, karena hal itu lebih mudah diterima." ${ }^{17}$

Manhaj al-salafu al-sālih dalam masalah ini adalah berusaha mengumpulkan hati manusia agar mencintai penguasa, serta menyebarkan rasa cinta antara rakyat dan penguasa. Seorang muslim, khususnya ulama, hendaknya senantiasa menasihati penguasa dengan rahasia, memperingatkan penguasa dari kemunkaran secara umum tanpa menyebutkan individu orangnya, seperti memperingatkan bahaya zina secara umum, riba secara umum, korupsi (penyelewengan) secara umum dan yang lainnya. ${ }^{75}$

71 Ibid., 195.

72 Hadis riwayat Ibnu Abi Āshim, vol. 2, hadis no.507; Ahmad, vol. 3, hadis no.403; Hakim, vol. 3, hadis no.290; Hadis ini dishahihkan oleh al-Albāni dalam Zhilāl Jannah, hadis no. 507.

73 Diriwayatkan oleh Imām Bukhāri dan Muslim.

74 al-Hāfizh Ahmad bin Ali bin Hajar al-Asqalāni, Fathu al- Bāri, vol. 13, hadis no. 52.

75 Abdul Salām Barjas, Muamalatu al-Hukkām, 111. 


\section{Keempat: Bersabar atas kezaliman penguasa}

Bersabar atas kezaliman penguasa termasuk prinsip aqidah Ahlu al-Sunnah wa al-Jamā'ah. Allah berfirman, "Hai anakku, dirikanlah salat dan suruhlah (manusia) mengerjakan yang baik dan cegahlah (mereka) dari perbuatan yang munkar dan bersabarlah terhadap apa yang menimpa kamu. Sesungguhnya yang demikian itu termasuk hal-hal yang diwajibkan (oleh Allah)." 176

Rasulullah Saw. bersabda, "Barangsiapa melihat sesuatu yang ia benci dari penguasanya maka hendaklah ia bersabar. Barangsiapa yang meninggalkan jamaah (kaum muslimin) walau sejengkal maka dia mati dalam keadaan jahiliyah."77 Beliau juga bersabda, "Sesungguhnya akan ada setelahku para pemimpin yang mementingkan diri mereka sendiri, perkara-perkara yang kalian ingkari. Para sahabat bertanya, 'Wahai Rasulullah apa yang engkau perintahkan kepada kami?' Beliau menjawab, 'Hendaklah kalian menunaikan kewajiban kalian dan mintalah hak kalian kepada Allah'."178

Imām Hasan al-Basri menyatakan: "Ketahuilah kezaliman penguasa adalah salah satu dari kemurkaan Allah. Kemurkaan Allah tidaklah dihadapi dengan pedang, akan tetapi dengan takwa, tolaklah dengan doa, taubat dan menjauhkan dosa." Imam Ibnu Abi al-Izzi berkata, "Adapun taat kepada penguasa tetap wajib, sekalipun mereka zalim, karena tidak mentaati penguasa akan menimbulkan keburukan yang lebih besar dari kezaliman mereka. Bahkan sabar atas kezaliman penguasa adalah penghapus dosa dan melipatgandakan pahala. Karena tidaklah Allah menimpakan hal itu kecuali karena keburukan perbuatan kita sendiri. Balasan itu setimpal dengan perbuatan. Kita wajib bersungguh-sungguh meminta ampun kepada Allah, taubat dan memperbaiki diri. Maka apabila rakyat ingin membebaskan diri dari

76 al-Qur'ān, 31(Luqman): 17.

77 Hadis riwayat Bukhāri dan Muslim.

78 Hadis riwayat Bukhāri dan Muslim. 
kezaliman penguasa, hendaklah mereka mengawali dengan meninggalkan perbuatan zalim pada diri mereka sendiri." 79

Di dalam kitab Sirāj al-Muluk disebutkan, bahwa Abdul Malik bin Marwān, salah seorang penguasa kaum muslimin waktu itu berkata, "Berlaku adillah kepada kami wahai seluruh rakyat. Kalian menghendaki dari kami seperti pemerintahan Abu Bakar dan Umar, akan tetapi kalian tidak mau berjalan bersama kami dan tidak pula meneladani rakyatnya Abū Bakar dan Umar." 80

\section{Kelima: Tidak boleh memberontak}

Memberontak terhadap penguasa hukumnya adalah haram, walau bagaimanapun keadaan dan keburukan penguasa. Rasulullah Saw. bersabda, "Sebaik-baik penguasa adalah yang kalian mencintainya dan mereka mencintai kalian. Kalian mendoakannya dan mereka mendoakan kalian. Seburuk-buruk penguasa adalah yang kalian membencinya dan mereka pun membenci kalian, kalian mencacinya dan mereka mencaci kalian. Rasulullah ditanya, 'Wahai Rasulullah, tidakkah kita memberontak dengan pedang?' Beliau menjawab, 'Jangan, selama mereka masih menegakkan salat. Apabila kalian melihat sesuatu yang kalian benci dari penguasa kalian maka bencilah perbuatannya dan janganlah kalian mencabut ketaatan dari mereka. "81

Imam al-Barbahari berkata, "Tidak halal memerangi penguasa dan memberontak, sekalipun mereka itu zalim. Nabi Muhammad bersabda kepada Abū Dhar al-Ghifāri, 'Bersabarlah meski penguasa itu seorang budak Habashah.' Dan sabda beliau Saw. kepada kaum Anshar, 'Bersabarlah kalian, sampai kalian menjumpaiku di telaga.' Di dalam sunnah, tidak ada istilah memberontak kepada penguasa, karena hal itu

79 Ibnu Abi al-Izzi, Sharah Aqīdah Thahāwiyah, vol. 2 (Riyādh: al-Majlis al-Islāmi alĀsiawi, 1421H), 542.

80 Lukman Jamal, "Syubhat Para Pemberontak", dalam http://www.facebook.com/ note.php?note-id=193934492202\&comments\&ref $=\mathrm{mf}$ (19 Desember, 2009)

81 Hadis riwayat Muslim. 
akan membawa kerusakan agama dan dunia." 82 Imām Nawāwi berkata, "Adapun memberontak dan memerangi penguasa adalah haram berdasarkan kesepakatan kaum muslimin, sekalipun mereka zalim dan fasiq." 83

Sejarah telah mencatat kekejaman seorang yang bernama Hajjāj bin Yūsuf al-Tsaqāfi. Dia telah banyak membunuh jiwa, sampai sahabat yang mulia Abdullah bin Zubair terbunuh. Meskipun demikian para sahabat yang masih hidup waktu itu tidak menyusun kekuatan untuk memberontak, sebaliknya mereka tetap menganjurkan untuk mendengar dan taat. Zubair bin Ādī berkata, "Kami mendatangi Anas bin Malik mengeluhkan perihal Hajjāj. Anas menjawab, "Bersabarlah, karena tidaklah datang sebuah zaman kecuali yang setelahnya akan lebih buruk, hingga kalian berjumpa dengan Rabb kalian, aku mendengar ini dari Nabi kalian." 84

Salah satu makar dan tipu muslihat orang Yahudi yang membunuh Utsmān bin Affān adalah dengan berwasiat kepada pengikutnya,"Mulailah dengan mencela para penguasa kalian dan tampakkanlah bahwa hal itu sebagai amar ma'ruf nahi munkar maka hati manusia akan condong kepada kalian. Setelah itu ajaklah mereka untuk memberontak!" 85

Apabila terjadi kekacauan dan ketidakstabilan politik, para alsalaf al-sālih tidaklah menyalahkan penguasa mereka. Tetapi mereka lebih berintrospeksi diri. Sehingga poros dari keamanan dan kestabilan politik berada pada pihak rakyat. Dikisahkan ada seorang Khawārij yang datang menemui Ali bin Abī Thālib lalu berkata, "Wahai khalīfah Ali, mengapa pemerintahanmu banyak dikritik oleh orang, tidak sebagaimana pemerintahannya Abū Bakar dan Umar?' Sahabat Ali Menjawab, 'Karena

82 Abū Muhammad al-Hasan bin Ali bin Khalaf al-Barbahari, Syarhu al-Sunnah, vol. 3, dalam http://www/saaid.net/power point/227. pps - -II -- (15 Desember, 2009)

83 Imām Nawāwi, Syarah Shah̄̄h Muslim, vol. 12 (Mathba'ah Misriyah bi al-Azhar, 1349H), 229.

84 Hadis riwayat Bukhāri.

85 Ibnu Jarīr al-Thabari, Tārikh al-Rusul wa al-Muluk, vol. 4 (Dār Ma'ārif, tt.), 340. 
pada zaman Abū Bakar dan Umar yang menjadi rakyat adalah aku dan orang-orang yang sepertiku, sedangkan rakyatku adalah kamu dan orangorang yang sepertimu!!"'86

\section{Keenam: Mendoakan kebaikan kepada penguasa}

Abū Utsmān Saīd bin Ismail berkata, "Nasihatilah penguasa, perbanyaklah mendoakan kebaikan bagi mereka dengan ucapan, perbuatan dan hukum. Karena apabila mereka baik, rakyat akan baik. Janganlah kalian mendoakan keburukan dan laknat bagi penguasa, karena keburukan mereka akan bertambah dan bertambah pula musibah bagi kaum muslimin. Doakanlah mereka agar bertaubat dan meninggalkan keburukan, sehingga musibah hilang dari kaum muslimin. ${ }^{87}$ Fudhail bin Iyādh berkata, "Andaikata aku mempunyai doa yang mustajab, niscaya akan aku panjatkan untuk penguasa." 88

Imam al-Barbahari berkata, "Apabila engkau melihat orang yang mendoakan kejelekan bagi penguasa maka ketahuilah bahwa dia seorang pengikut hawa nafsu. Apabila engkau melihat orang yang mendoakan kebaikan bagi penguasa maka dia adalah pengikut sunnah, insha Allah."89

Diceritakan bahwa al-Hasan al-Basri pernah mendengar seseorang mendoakan al-Hajjāj dengan keburukan maka dia berkata, "Janganlah kamu berbuat demikian, -semoga Allah merahmati kamusesungguhnya apa yang menimpa diri kalian adalah disebabkan perbuatan diri kalian sendiri. Sesungguhnya kami khawatir seandainya

86 Ibnu Utsaimīn, Sharah Riyādh al-Salihīn, vol.3 (Mu'assasah Shaikh Ibnu Utsaimīn, 2004), 43.

87 Abū Bakar Ahmad bin Al-Husain al-Baihaqi, Shu'abu al-Imān, vol. 13, hadis no. 99.

88 Abū Nu'aim Ahmad bin Abdillah al-Asbahani, Hilyatu al-Awliyā wa Thabaqatu alAsfiyā', vol. 8 (Beirut: Dār al-Kitāb al-Arabi, 1405), 91.

89 al-Barbahari, Syarhu al-Sunnah, 113. 
Hajjaj dicopot dari jabatannya atau wafat, justru akan datang seorang pemimpin yang berwatak kera atau babi." 90

\section{Ketujuh: Tidak mudah mengkafirkan penguasa}

Takfir (mengkafirkan seseorang) adalah merupakan hak Allah maka tidak boleh dilontarkan kecuali kepada orang yang berhak dikafirkan. Karena mengkafirkan seseorang dengan sembarangan tanpa hujjah maka kekufuran itu akan kembali kepada yang menuduh. Nabi bersabda,

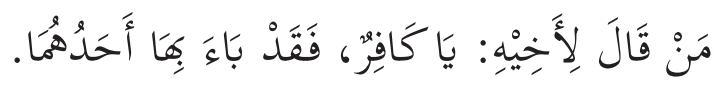

"Barangsiapa mengatakan kepada saudaranya, 'Wahai kafir', maka (tuduhan tersebut) akan kembali kepada salah satu dari keduanya. "191

Mengkafirkan penguasa akan menimbulkan berbagai kerusakan dan dampak negatif yang jauh lebih besar daripada mengkafirkan rakyat biasa. Karena itu, al-salafu al-sālih menetapkan bahwa penguasa tidak boleh dikafirkan, kecuali memenuhi beberapa syarat:

1. Kekufurannya nyata, tidak ada kesamaran lagi.

2. Ada kejelasan bukti yang nyata dari al-Qur’ān dan al-Sunnah serta Ijma $\bar{a}^{\prime}$ tentang kekufurannya. Dari Ubādah bin al-Shāmit, ia berkata,
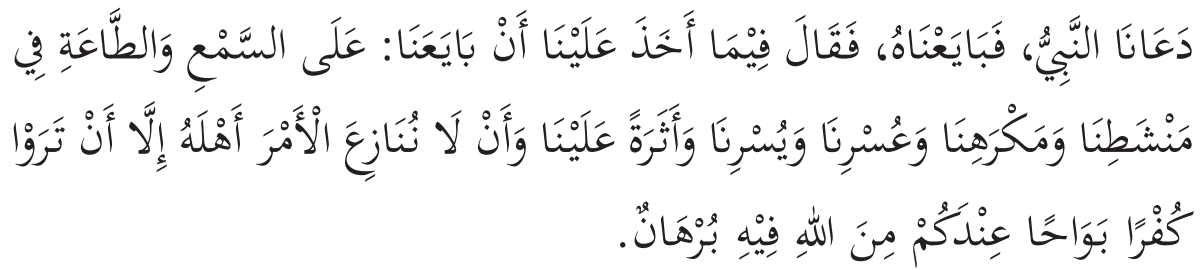

"Nabi Saw. mendakwahi kami maka kami berbai'at kepada beliau. Kemudian beliau mengatakan tuntutan yang wajib kami penuhi apabila

90 Ibnu al-Jauzi, Adab al-Hasan al-Basri wa Zuhduhu wa Mawa'idhuhu (Dār alNawādir, 1426), 119.

91 Muttafaq Alaih. 
beliau membai'at kami, (ialah): Mendengar dan taat (kepada pemimpin) dalam keadaan suka atau terpaksa, ketika dalam kemudahan ataupun sulit, dan (sekalipun) sewenang-wenang terhadap kami, dan agar kami tidak merampas kekuasaan dari pemiliknya, kecuali jika kalian melihat kekufuran yang nyata, dan kalian mempunyai bukti yang nyata dari Allah dalam hal itu." 92

3. Pihak yang berhak memvonis kafir dan tidaknya adalah ulama. Allah berfirman,

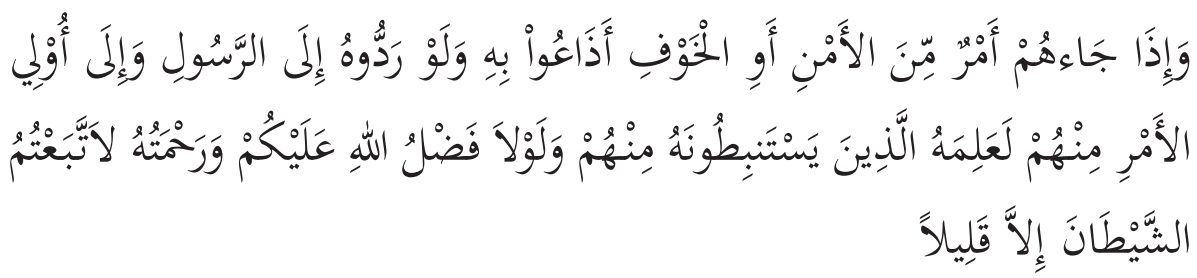

"Dan apabila datang kepada mereka suatu berita tentang keamanan ataupun ketakutan, mereka lalu menyiarkannya, dan kalau mereka menyerahkannya kepada Rasul dan ulil amri di antara mereka, tentulah orang-orang yang ingin mengetahui kebenarannya (akan dapat) mengetahuinya dari mereka (rasul dan ulil Amri), kalau tidak karena karunia dan rahmat Allah kepada kamu, tentulah kamu mengikuti setan, kecuali sebagian kecil saja (di antaramu). ${ }^{\prime 19394}$

\section{Hubungan dengan Non Muslim menurut al-Salaf al-Sālih}

Praktik hidup bermasyarakat dan bernegara Rasulullah Saw. dan para sahabatnya, khususnya waktu di Madinah adalah teladan dan panutan kaum muslimin dalam hubungan mereka dengan orang-orang non muslim. Nabi Muhammad dan para sahabatnya di dalam masyarakat

92 Hadis riwayat Bukhari dan Muslim.

93 Al-Qur'ān, 4 (al-Nisa'): 83.

94 Sulaimān bin Salīmullah al-Ruhaili, "Prinsip Menjalin Hubungan dengan Penguasa", dalam http:// www.almanhaj,or.id/content/2545/slash/0 (20 Februari 2010) 
Madinah hidup berdampingan dengan harmonis dalam sebuah masyarakat yang plural bersama orang-orang Yahudi dan Nashrani. Nabi Muhammad membuat perjanjian dalam hidup bermasyarakat dengan non muslim di Madinah dalam sebuah perjanjian yang disebut sebagai Piagam Madinah. Tidak hanya dalam praktik, secara verbal Nabi Muhammad juga memberikan petunjuk berkaitan dengan hubungan dengan orang-orang non muslim dalam kehidupan bermasyarakat.

Rasulullah Saw. melarang kaum muslimin mengganggu orangorang non Islam yang hidup sebagai kafir dhimmī. Yaitu orang kafir yang termasuk warga negara kaum muslimin ${ }^{95}$ yang dilindungi selama mereka mentaati peraturan-peraturan negara dan membayar jizyah (semacam upeti atau pajak). Rasulullah Saw. bersabda: "Sesungguhnya Allah tidak mengijinkan kalian untuk masuk ke rumah orang-orang ahli kitab kecuali dengan seijin mereka, tidak boleh memukul mereka dan mengambil buah-buahan mereka selama mereka memberikan kepada kalian kewajiban mereka."

Orang-orang non muslim yang bukan warga negara, tetapi terikat perjanjian damai, seperti para pendatang dari negara asing yang tidak dalam keadaan berperang (dengan muslim) atau dalam kata lain terikat perjanjian damai maka kaum muslimin tidak boleh mengganggu, apalagi

95 Di sini tidak digunakan istilah negara Islam, tetapi negara kaum muslimin. Suatu negara yang mayoritas penduduknya kaum muslimin, meskipun tidak sepenuhnya undang-undang negara tersebut sesuai dengan ajaran Islam adalah disebut sebagai negara kaum muslimin, berdasarkan hukum mayoritas. Apalagi jika tidak ada pelarangan terhadap shi'ar-shi'ar kaum muslimin yang utama seperti shalat Jum'at, adzan dengan loud speaker luar, pengajian umum dan kegiatan-kegiatan islami lainnya. Jika demikian keadaannya maka negara tersebut adalah negara kaum muslimin. Demikian menurut Shaikh Muhammad bin Shalih al-Utsaimin dalam tafsir Juz Amma saat beliau membahas tentang bilād al muslimīn (negara kaum muslimin). Berdasarkan pendapat tersebut maka negara Indonesia adalah negara kaum muslimin, yang berlaku padanya hukum-hukum fikih yang berkaitan dengan tata pemerintahan Islam, seperti kafir dhimmi, kafir mu'āhad, utusan negara asing dan sebagainya. Lihat Muhammad bin Shālih al-Utsaimīn, Tafsīr al-Qur'ān alKarīm Juz Amma (Dār al-Tsuraya, 2002), 62.

96 Diriwayatkan oleh Abu Dawud. 
membunuh mereka selama mereka mentaati perjanjian tersebut. Demikian pula duta-duta asing yang tinggal di negara kaum muslimin. Rasulullah Saw. mengancam orang-orang yang mengganggu atau menzalimi mereka. Mereka ini diistilahkan dengan kafir mu'ahad (yang terikat perjanjian). Rasulullah Saw. bersabda, "Ketahuilah barang siapa menzalimi seorang mu'ahad; atau mengurangi hak-haknya; atau membebaninya di luar kemampuannya; atau mengambil sesuatu daripadanya tanpa keridlaannya. Maka aku akan menjadi penentangnya pada hari kiamat."197

Apalagi membunuh seorang mu'āhad, Rasulullah Saw. lebih keras lagi mengancamnya, "Barangsiapa membunuh seorang mu'ahad, maka ia tidak akan mencium bau surga, padahal harumnya surga didapati dari jarak 40 tahun perjalanan." 98 Kalau pendatang nonmuslim itu merupakan utusan, walaupun utusan itu dari negara kafir yang sedang berperang dengan negara kaum muslimin, shariat Islam tidak membolehkan menangkap, menahan atau membunuh para utusan tersebut, yang dalam shari'at Islam istilahnya adalah wufüd. Suatu hari Rasulullah Saw. didatangi dua orang utusan dari Musailamah al-Kadzāb, seorang nabi palsu yang memusuhi Rasulullah. Kemudian beliau bersabda, "Apakah kalian mau bersaksi bahwa Muhammad adalah Rasulullah?" Mereka berkata, "Kami bersaksi bahwa Musailamah adalah Rasulullah." Maka Rasulullah Saw. bersabda, "Aku beriman kepada Allah dan para rasul-Nya! Kalau saja aku membolehkan untuk membunuh seorang utusan, tentu akan aku bunuh kalian berdua!" Bahkan walaupun utusan kafir tersebut kemudian masuk Islam, Rasulullah tetap memerintahkannya untuk kembali kepada kaum yang mengutusnya sebagaimana diriwayatkan dari Abū Rafī' sebagai berikut, "Aku diutus oleh orang-orang kafir Quraisy menemui Rasulullah Saw. Ketika aku melihat beliau, masuklah Islam ke dalam hatiku. Maka aku mengatakan kepada beliau, "Wahai Rasulullah, demi Allah aku tidak

97 Diriwayatkan oleh Abu Daud dan Baihaqi. Lihat pula al-Albāni, al-Shahīhah,vol. 1, no.807.

98 Diriwayatkan oleh Imam Bukhari. 
akan kembali kepada mereka selama-lamanya." Maka Rasulullah Saw. bersabda, "Sesungguhnya aku tidak akan melanggar perjanjian dan tidak akan menahan para utusan. Maka kembalilah engkau! Kalau pada dirimu tetap ada keimanan seperti sekarang ini maka kembalilah engkau kemari." 99 Dalam riwayat lain dikatakan, "Sesungguhnya aku tidak melanggar janji dan tidak akan menangkap seorang utusan." 100

\section{Kesimpulan}

1. Kaum al-salaf al-sālih adalah mereka yang berpegang teguh terhadap al-Qur'an dan al-Sunnah dengan menjaga otentitas pemahamannya sebagaimana yang dulu diajarkan oleh Rasulullah Saw. dan dipahami oleh para sahabat. Generasi awal al-salaf al-sālih adalah Nabi Muhammad dan para sahabat. Selanjutnya para tābi'ìn dan tābi'ut tābi'în. Mereka itulah yang disebut sebagai tiga generasi paling utama dan paling baik di dalam Islam. Orang yang komitmen dengan ajaran dan pemahaman mereka (al-salaf al-sālih) disebut sebagai salafi (pengikut salaf) atau istilah populernya ahlu al-sunnah wa aljamā'ah. Para salafiyyūn (orang-orang salaf) itu memiliki sanad pemahaman ajaran Islam hingga kepada Rasulullah Saw. Sehingga, di mana pun seseorang berada, pada jaman kapan pun ia hidup, selama punya komitmen untuk berpegang teguh kepada al-Qur'an dan al-Sunnah sesuai pemahaman para al-salaf al-sālih maka ia adalah salafi, baik dia menamakan diri sebagai salafi atau tidak.

2. Kaum al-salaf al-sālih memiliki prinsip-prinsip yang jelas dan tegas tentang sikap rakyat (kaum muslimin) kepada penguasanya. Yaitu meyakini wajibnya mentaati amīr al-mukminīn (penguasa yang sah dari kaum muslimin), betapa pun keadaan penguasa itu, baik atau buruk, selama ia masih tetap muslim dan menjalankan salat. al-Salaf al-Sālih mewajibkan kaum muslimin untuk berbai'at (taat) kepada pemimpinnya dan menghormati mereka, menasihati mereka secara

99 Hadis riwayat Abu Daud, Nasa'i, Ibnu Hibbān, Hākim dan Ahmad.

100 Hadis riwayat Abu Daud dan Nasa'i. 
rahasia, bersabar atas kezaliman mereka, mendoakan kebaikan untuk mereka, tidak memberontak dan tidak mudah mengkafirkan mereka, kecuali setelah memenuhi sharat-sharatnya.

3. Orang-orang yang melakukan tindakan terorisme dengan melakukan pengeboman secara membabi buta, karena meyakini telah kafirnya sang penguasa yang dipilih secara sah oleh kaum muslimin, tidak percaya dan mengingkari ketaatan kepada pemimpin kaum muslimin, lalu mengaku bahwa diri mereka sebagai pengikut al-salaf al-sālih adalah pengakuan yang tidak berdasar dan bertolak belakang dengan kenyataan yang sesungguhnya. al-Salaf al-Sālih berlepas diri dari keburukan perbuatan mereka, sebab dalam akidah al-salaf al-salih bila seorang penguasa sudah disepakati oleh kaum muslimin maka dia adalah penguasa dan pemimpin sah kaum muslimin yang wajib ditaati, betapapun keadaan mereka. Jika yang dilakukan adalah sebaliknya maka mereka bukanlah pengikut al-salaf al-sālih, tetapi orang-orang khawarij yang suka memberontak kepada pemimpin kaum muslimin.

4. Istilah salaf, salafi, dan al-salaf al-sālih adalah derivasi dari satu akar kata "salafa" yang merujuk kepada pengamalan Islam sebagaimana yang diamalkan oleh para sahabat, murid-murid didikan langsung Rasulullah Saw. Ia adalah istilah yang mulia dan agung dalam sejarah dan khazanah Islam. Karena itu, setiap muslim tidak boleh gegabah dalam menggunakan istilah tersebut, apalagi untuk stigmatisasi dan konotasi yang buruk. Mengaitkan aksi pengeboman, terorisme dan sejenisnya kepada kaum salafi adalah bentuk stigma yang akan menodai kemuliaan istilah salaf, salafi, dan al-salaf alsālih. Sebab kenyataannya, para pelaku pengeboman yang mengaku sebagai salafi, perilaku mereka justru bertentangan dengan ajaran alsalaf al-sālih. 


\section{Daftar Pustaka}

al-Qur'ān Terjemah. Depag RI.

al-Aql, Nāsir bin Abdul Karīm. Mujmal Usūl Ahli al-Sunnah wa alJamā'ah fì al-Aqīdah. Dār Ma'ārif, 1427H.

al-Anbari, Khālid. Fiqh al-Siyāsah al-Shar'iyah. Dār Minhaj, 1428H.

al-Asbahani, Abū Nu'aim Ahmad bin Abdillah. Hilyatu al-Awliya wa Thabaqātu al-Asfiyā'. Beirut: Dār al-Kitāb al-Arabi, 1405.

al-Asqalani, Al-Hāfizh Ahmad bin Ali bin Hajar. Fathu al-Bāri bi Sharh Sahīh al-Bukhāri. Tahqīq Shaikh Abdul Aziz bin Abdullah bin Bāz, Dār al-Fikr, tt.

al-Atsari, Abdullah bin Abdul Hamid. Al-Wajīz fi Aqīdati al-Salaf alSālih. Dār Ibnu Huzaimah, tt.

al-Baihaqi, Abū Bakar Ahmad bin Al-Husain. Shu'abu al-Imān. Beirut:Dār al-Kutub al-Ilmiyyah, 1410H.

al-Barbahari, Abū Muhammad al-Hasan bin Ali bin Khalaf. Sharhu al-Sunnah. Dār al-Mālayin, tt.

al-Bukhari, Imam al-Hāfizh Abū Abdillah Muhammad bin Ismaīl bin Ibrāhīm bin al-Mughīrah bin Bardizbah. al-Jāmi' al-Musnad al-Sahīh al-Mukhtashar min Umūri Rasulillah wa Sunanihi wa Ayyāmihi. Riyādh: Dārussalām, 1420H.

al-Buraikan, Ibrāhīm bin Muhammad bin Abdillah. Ta'rif al-Khalaf bi Manhaj al-Salaf. Dar Ibnu al-Jauzi, 1997.

al-Daraibi, Isā bin Nasir. Min Ma'ālim al-Taisir fì Tafsìri al-Salaf. Saudi Arabia: Wizārah Syu'ūn Islamiyah, 1428H.

al-Dimashqi, Imāduddīn Abū al-Fida' Ismāīl bin Katsīr al-Qurashi. Tafsìr al-Qur'ān al-Adzīm. Riyādh: Maktabah Faihā',1414H.

al-Dimashqi, al-Imām al-Qādhi Ali bin Ali bin Muhammad, bin Abi al-Izz. Sharah Aqīdah Thahāwiyah. Al-Majlis al-Islāmi alĀsiawi, 2000. 
Ainul Haris

al-Ghazāli. Imām Abu Hamid. Iljāmu al-Awām an Ilmi al-Kalām. Dār al-Fikr al-Lubnāni, 1993.

al-Hilāly. Salim bin Ied. Limādza Ikhtartu al-Manhaj al-Salafi. Markaz al-Dirāsāt al-Islāmiyah, 1420H.

al-Jauzi, Ibnu. Adabu al-Hasan al-Basri wa Zuhduhu wa Mawā'idzuhu. Dar al-Nawādir, 1426.

al-Maqdisi, Muhammad bin Muflih bin Muhammad. al-Adab alShar'iyyah wa al-Minah al-Mar'iyyah. Alamu al-Kutub, tt.

al-Naisaburi, Imām al-Hāfizh Abu al-Husain Muslim bin al-Hajjāj, bin Muslim al-Qushairi. Al-Musnad al-Sahīh al-Mukhtasar min alSunan binaqli al-Adl an Adl an Rasulillah. Dārussalām, $1420 \mathrm{H}$.

al-Nasa'i, Imām al-Hāfizh Abū Abdirrahmān Ahmad bin Shu'aib bin Ali bin Sinān. al-Mujtaba min al-Sunan. Riyādh: Dārussalām, $1420 \mathrm{H}$.

al-Qazwaini, Imām al-Hāfizh Abū Abdillah Muhammad bin Yazīd alRab'i Ibnu Mājah. Sunan Ibnu Mājah. Riyādh: Dārussalām, $1420 \mathrm{H}$.

al-Qurthubi, Al-Imām Abū Abdillah. al-Jāmi' li Ahkami al-Qur'ān (Tafsīr al-Qurthubi). Tahqīq Hisham Samīr al-Bukhāri, Riyādh: Dār Alam al-Kutub, 2003.

al-Ruhaili, Ibrāhīm bin Amīr. al-Takfìr wa Dhawābithuh. Dār Imām Ahmad, 2008.

al-Sajistāni, Imām al-Hāfizh Abū Daud Sulaimān bin al-Ash'ats bin Ishaq al-Azdi. Sunan Abī Daud. Riyādh: Dārussalām, 1420H. al-Thabari, Ibnu Jarīr. Jāmi' al-Bayan an Ta'wīl Ayi al-Qur'ān. Maktabah Ibnu Taimiyah, tt. . Tārīikh al-Rusul wa al-Muluk. Dār Ma'ārif. tt.

al-Tirmidzi, Imām al-Hāfizh Abū Isā Muhammad bin Isā bin Surah bin Mūsā. al-Jāmi' al-Mukhtasar min al-Sunan an Rasulillah wa Ma'rifati al-Sahīh wa al-Ma'lūl wamā Alaihi al-Amal. Riyādh: Dārussalām, 1420. 
Barjas, Abdus Salam. Muāmalatu al-Hukkām fì Dhau'i al-Kitāb wa alSunnah. Dammām: Dār Sabīli al-Mukminīn, 1414.

Bashīr, Abū Umar. Aku Bukan Salafi? Menjernihkan Kesalahpahaman tentang Salaf dan Salafi. Unaizah Media, 2009

Faris, Ibnu. Mu'jamu Maqāȳ̄s al-Lughah. Riyādh: Dār Thaibah, $1416 \mathrm{H}$.

Fealy, Greg; Antony Bubalo. Jejak Kafilah: Pengaruh Radikalisme Timur Tengah di Indonesia. Bandung: Mizan Pustaka, 2007.

Hāris, Ainul. 30 Wasiat Takwa di Bulan Puasa. Riyādh: Dār al-Kitāb wa al-Sunna, 2009.

Hasan, Noorhadi. Laskar Jihad, Islam, Militansi dan Pencarian Identitas Pasca Orde Baru. Jakarta: LP3S.

Himpunan Ulama Besar Saudi Arabia. Fatāwā Lajnah Dā'imah. Wizārah Shu'un Islāmiyah, 1428.

International Crisis Group. Why Salafism and Terrorism Mostly Don't Mix. 2004.

Jawas, Yazīd Abdul Qādir. Sharah Aqīdah Ahlu al-Sunnah wa alJamā'ah. Bogor: Dār al-Taqwa, 2007.

Manzhūr, Ibnu. Lisān al-Arab. Riyādh: Dār Alam al-Kutub, 1416H.

Mubārak, M.Zaki. Geneologi Islam Radikal di Indonesia, Gerakan, Pemikiran dan Prospek Demokrasi. Jakarta: LP3S, 2008.

Nasr, Musā. Silsilah Abhāts Manhajiyyah al-Salafiyyah. Dār Ma'rifah, $1428 \mathrm{H}$.

Nawāwi, Imām. Sharah Sah̄̄h Muslim. Matba'ah Misriyah bi alAzhar, $1349 \mathrm{H}$.

Quthb, Sayid. F̄̄ Zhilāl al-Qur'ān. Dār al-Shurūq, 1980.

Salām, Ahmad. Mā Ana Alaihi wa Ashābī. Dār Ibn Hazm, 1995 
Ainul Haris

Taimiyah, Ibnu. Majmu' Fatāwā. Tart̄̄b Abdurrahmān bin Muhammad bin Qāsim al-Āshimi al-Najdi al-Hambali, Dār alMālayin, tt.

Utsaimīn, Ibnu. Sharah Riyādhus Sālihīn. Mu'assasah Shaikh Ibnu Utsaimīn, 2004.

Zainu, Muhammad bin Jamīl. Jalan Golongan yang Selamat. terj. Ainul Haris Umar Arifin Thayib, Jakarta: Darul Haq, 1998.

Zuhairini, et.al. Sejarah Pendidikan Islam. Jakarta: Bumi Aksara, 2008.

\section{Internet:}

Al-Barbahari, Abū Muhammad al-Hasan bin Ali bin Khalaf. "Sharhu al-Sunnah. vol. 3", dalam http://www/saaid.net/power point/227. pps - -II -- (15 Desember, 2009)

Indonesia Faithfreedom. "Upaya Pembentukan Negara Islam NII dan Penerapan Syariat Islam", dalam http://indonesia.faithfreedom.org/forum/upaya-pembentukannegara-islam-nii-dan-penerapan-syariat-t10521 (22 Pebruari 2010)

Subagja, Indra. "Surat Pengakuan Nur Din M. Top atas Tragedi Marriot dan Ritz". dalam http://www. detiknews.com/read/2009/07/29. (22 Pebruari 2010)

Jamal, Lukman. "Syubhat Para Pemberontak". dalam http://www.facebook.com/ note.php?note$\mathrm{id}=193934492202 \&$ comments\&ref=mf. (19 Desember, 2009)

Ikhsan, Muhammad. "Gerakan Salafi Modern di Indonesia, Sebuah Upaya Membedah Akar, Pertumbuhan dan Ide-ide Substansinya”. dalam http://alquranandsunnahwordpress.com/2009/02/05/gerakan-salafi-modern-diindonesia/\#more-1025. (20 Desember 2009) 
Al-Ruhaili, Sulaimān bin Salīmullah. "Prinsip Menjalin Hubungan dengan Penguasa". dalam http:// www.almanhaj,or.id/content/2545/slash/0 (20 Pebruari 2010)

Tempo interaktif, "Wendy, Abu, Icuh dan Ju", dalam http://majalah. tempointeraktif.com/id/arsip/1981/04/11/NAS/mbm.19810411. NAS49234.id.html (22 Pebruari 2010)

al-Qaradhāwi, Yusuf. "Quthb Bertanggung Jawab atas Berkembangnya Islam Radikal". dalam http:// dunia.pelajarislam or.id/dunia.pii/2009/08/10. (20 Desember, 2009) 